\title{
TRABALHADORES NA EXTRAÇÃO DE RESINA NA MESORREGIÃO DE ITAPETININGA (SP)
}

REGINA ANTONIA LIBERAL VALENTINO FREIRE

Engenheira Florestal

Orientador : Prof. Dr. ORIOWALDO QUEDA

Dissertação apresentada à Escola Superior de Agricultura "Luiz de Queiroz", Universidade de São Paulo, para obtenção do título de Mestre em Ciências, Área de concentração: Ciências Florestais.

PIRACICABA

Estado de São Paulo - Brasil

Fevereiro - 2000 
Dados Internacionais de Catalogação na Publicação (CIP) DIVISĀO DE BIBLIOTECA E DOCUMENTAÇĀO - Campus "Luiz de Queiroz"/USP

\author{
Freire, Regina Antonia Liberal Valentino \\ Trabalhadores na extração de resina na mesorregião de Itapetininga (SP) / Regina \\ Antonia Liberal Valentino Freire. - - Piracicaba, 2000. \\ 86 p. : il.
}

Dissertação (mestrado) - - Escola Superior de Agricultura Luiz de Queiroz, 2000. Bibliografia.

1. Extração de resina 2. Pinheiro 3. Trabalhador I. Título

CDD 634.9751 


\section{DEDICATÓRIA}

Ofereço este trabalho às pessoas que eu amo.

Orlando, meu marido, que sempre apoiou, incentivou e consolou, com carinho e paciência, principalmente quando os tropeços quase me derrubavam.

Aos meus filhos: Carlos Eduardo, Nina, Alexandre, Luis, Mariana e Talita que tiveram a generosidade de perdoar as ausências. 


\section{Agradecimentos}

Agradeço sinceramente a todos que direta ou indiretamente colaboraram para a realização deste trabalho. Agradeço em especial:

- ao Prof. Oriowaldo Queda pela orientação e atenção;

- ao Instituto Florestal que possibilitou a sua realização;

- ao PqC Marco Antonio de Oliveira Garrido pelo apoio e estímulo;

- ao PqC Antonio Orlando da Luz Freire Neto, pelas inúmeras revisões e sugestões;

- ao PqC Antonio Cecílio Dias e aos demais colegas da Estação Experimental de Itapetininga, pelo apoio e sugestões;

- ao PqC Mário de Almeida Fagundes pela atenção e valiosas informações;

- a Associação dos Resineiros do Brasil, ARESB, na pessoa do seu Presidente Sr. Jurandir Proença e aos associados que possibilitaram as entrevistas e disponibilizaram informações;

- ao Prof. Antonio Natal Gonçalves pelo amplo apoio, e aos Professores do Departamento de Ciências Florestais pelas informações e sugestões;

- à Profa. Ednéa Motta Ramos pela leitura do texto e correções gramaticais;

- à Bibliotecária Ligiana Clemente pela atenção no atendimento e auxilio nas revisões bibliográficas;

- ao Sr. Walter Miguel Nogueira pela colaboração nos trabalhos de campo;

- Aos colegas do curso de pós-graduação pelo convívio amistoso. 


\section{SUMARIO}

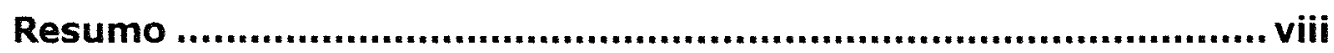

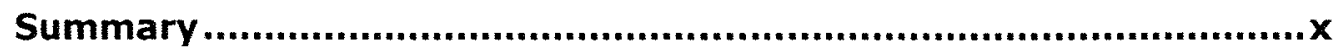

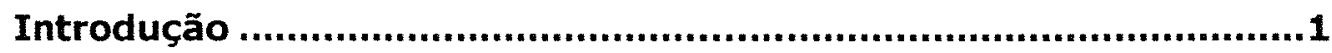

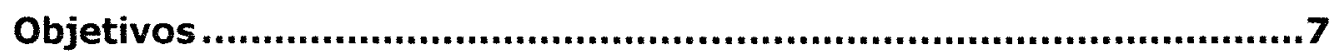

A Região e suas características..........................................................8

Perfil Histórico ...........................................................................14

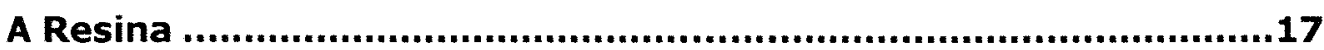

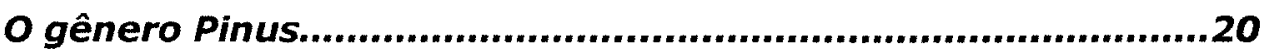

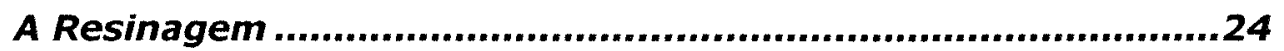

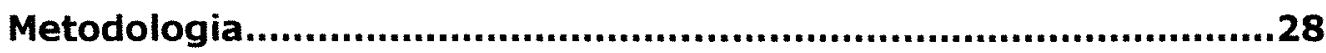

Características das moradias...................................................30

O Processo de trabalho na resinagem .............................................36

A resinagem em áreas do Instituto Florestal ...........................55

Caracteristicas do trabalhador da resinagem ............................58

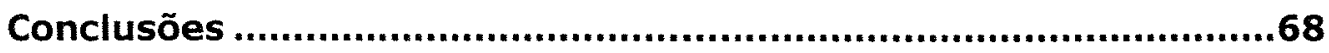


Referências Bibliográficas........................................................70

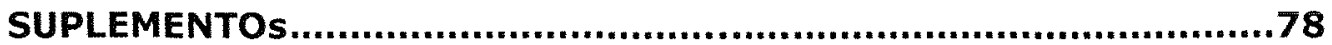

1. Questionários................................................................78

2. Trabalhos sobre Resinagem...............................................81 


\section{LISTA DE FIGURAS}

Localização da Mesorregião de Itapetininga - SP ........................................8

Levantamento de aptidão florestal das terras (FF, 1993) ..........................13

Cadeia produtora do Pinus (Caser, 1998) ..............................................19

Distribuição do Pinus no Estado de São Paulo (São Paulo, 1974) .................. 21

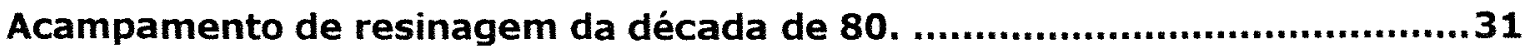

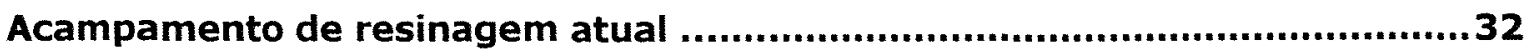

Resinagem utilizando o método das calhas pregadas .................................43

Resinagem pelo método do saquinho. .................................................... 44

Operação de estriagem e aplicação da pasta ácida. ....................................48

Feitura da estria em "V" .......................................................................49

Operação de coleta da goma resina. .........................................................49

Operação de revisão.................................................................................50

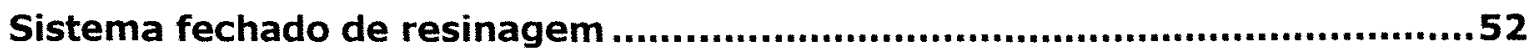




\section{LISTA DE TABELAS}

Tabela 1 : Características da Mesorregião de Itapetininga

9

Tabela 2: Ocupação do solo da Mesorregião de Itapetininga e do Estado de São Paulo

Tabela 3: Tempo de estudo na Mesorregião de Itapetininga, para pessoas com mais de 10 anos de idade

Quadro 4: Evolução do reflorestamento com Pinus e Eucalyptus, em área (ha) no período de 1978 a 1992, nas sub-regiões de Avaré, Botucatu, Itapetininga

e Tatuí 23

Tabela 5: Reflorestamento com Pinus e Eucalyptus na Mesorregião de Itapetininga e no Estado de São Paulo.

Quadro 6: Cronologia histórica da resina................................................25

Quadro 7: Custos médios de insumos para a resinagem .............................45

Tabela 8: Relação entre tempo de trabalho e tempo de moradia no acampamento estudado

Tabela 9: Relação entre tempo de trabalho e tempo de moradia no bairro estudado

Tabela 10: Relação entre o tempo de trabalho na resina e o tempo morando na colônia estudada 


\title{
TRABALHADORES NA EXTRAÇÃO DE RESINA NA MESORREGIÃO DE ITAPETININGA (SP)
}

\author{
Autora: REGINA ANTONIA LIBERAL VALENTINO FREIRE \\ Orientador: Prof. ORIOWALDO QUEDA
}

\section{Resumo}

Com o objetivo de buscar um entendimento e a importância da atividade resineira na Mesorregião de Itapetininga, SP, procurou-se conhecer a atividade do ponto de vista do trabalhador, das suas condições de vida e das relações trabalhistas presentes na atividade. A resina é extraída de Pinus e constituí-se de breu e terebintina. Na Mesorregião de Itapetininga, se localiza a maior parte da resinagem do Estado de São Paulo. Foi feita uma abordagem qualitativa do assunto, amostrando-se empresas de tamanhos diferentes. Foram empregadas entrevistas semi-estruturadas, complementadas com conversas com empresários da Associação de Resineiros do Brasil - ARESB, Pesquisadores do Instituto Florestal - IF, e familiares dos trabalhadores. Também foi usada observação, principalmente em relação às condições de moradia. Foram abordadas 
três situações de moradia de trabalhadores da resinagem: acampamento, colônia e bairro rural, sendo que o acampamento e a colônia se localizam na floresta explorada e 0 bairro nas proximidades. Apurou-se que as transformações das formas de resinar a árvore tiveram como objetivos a sua preservação e a redução de custos, sendo que o trabalhador é atualmente o maior componente destes custos. Está sendo pesquisado um novo método de resinagem: o sistema fechado de extração de resina, onde o número de trabalhadores necessários se reduz drasticamente. A maior parte da resinagem é realizada em florestas de terceiros, havendo poucos empresários resinando em áreas próprias. A redução da área plantada com Pinus, no Estado de São Paulo, está causando a mudança da atividade para outros Estados, onde o reflorestamento com Pinus resineiros ainda é abundante. A legislação e a fiscalização do Ministério do Trabalho, obrigaram a retirada do menor de 14 anos de dentro da floresta e obrigaram o pagamento de vantagens trabalhistas. 


\title{
WORKERS IN THE RESIN EXTRACTION IN MESORREGIÃO OF ITAPETININGA (SP)
}

\author{
Author: REGINA ANTONIA LIBERAL VALENTINO FREIRE \\ Adviser: PROF. ORIOWALDO QUEDA
}

\section{Summary}

With the objective of looking for an understanding and the importance of the gum resin activity in Mesorregião of Itapetininga, SP, tried to know the activity of the worker's point of view, of its life conditions and of the relationship of work presents in the activity. The gum resin is extracted of Pinus and I was constituted of colophony and turpentine. In Mesorregião of Itapetininga, it is located most of the extraction of gum resin of the State of São Paulo. It was made a qualitative to broach a subject, being made samplings of companies of different sizes. Semistructured interviews were used, complemented with chats with managers of the Associação dos Resinadores do Brasil - ARESB, Researchers of the Forest Institute IF, and family of the workers. Observation was also used, mainly in relation to the dwelling conditions. Three situations of workers' of the gum resin extraction dwelling were approached: camp, colony and rural neighborhood, and the camp and the colony are located in the explored forest and the neighborhood in the proximities. It hurried that the transformation in the to extract gum resin ways the tree had as objectives the preservation of the tree and the reduction of costs, being now the worker the largest component of these costs. This being researched a new 
extraction of resin way: the shut system of extraction of gum resin, where the number of necessary workers is reduced drastically. Most of the extraction of gum resin is accomplished at forests of third, having few managers gum resin producers in own areas. The reduction of the planted area with Pinus in the São Paulo State is causing the change of the activity for another States, where the reforestation with Pinus producer of gum resin is still abundant. The legislation and the fiscalization of the Ministry of the Work, they forced the 14 year-old smallest's retreat from within of the forest and they forced the payment of labourites advantages. 


\section{INTRODUÇÃO}

A História do Brasil, em muitos momentos, se entrelaça com a atividade madeireira: o que primeiro despertou o interesse de Portugal e de outras potências, nesta terra, foram as grandes extensões florestais abundantes em pau brasil (Caesalpinia echinata Lam.), importante pelo corante vermelho, extraído do seu tronco. Depois, no final do século passado $e$ inicio deste, foi a vez da exploração da seringueira (Hevea brasiliensis Muell. Arg.) colocar o Brasil em posição de destaque no cenário mundial. Atualmente, a exploração madeireira da Amazônia, feita de forma irresponsável e sem critérios, mais uma vez causa preocupação. O extrativismo predatório levou ao quase desaparecimento de recursos florestais valiosos.

A expansão da fronteira agrícola, principalmente em São Paulo, por causa da cana-de-açúcar e do café, tornou conveniente a introdução das ferrovias. O resultado foi o consumo crescente de madeira para uso nas caldeiras das locomotivas, como dormentes e postes. A escassez dessa madeira, fez surgir o eucalipto como opção de suprimento energético.

Com o avanço da cafeicultura para o norte do Paraná, foram derrubadas grandes extensões de matas de pinheiros. O abastecimento de madeira branca, que era usada principalmente na fabricação de papel, construção civil e movelaria, ficou comprometido. Assim, na década de 50, são introduzidas as primeiras espécies de Pinus para minimizar os impactos da demanda de madeira branca. 
A devastação das matas brasileiras, principalmente no território paulista, seguia em ritmo acelerado, com a justificativa do desenvolvimento e do progresso, sendo necessárias medidas governamentais que revertessem a situação. As providências adotadas foram a preservação de áreas naturais através da criação de parques e reservas naturais, áreas de proteção, etc. Para suprir a demanda de madeira foram tomadas medidas visando principalmente o estímulo ao uso de madeiras exóticas de rápido crescimento como os gêneros Eucalyptus e Pinus. Para tanto, foram criadas as Estações Experimentais com o objetivo de plantar, pesquisar e difundir a utilização destas espécies.

Assim, em 28 de novembro de 1958, foi criada oficialmente a Estação Experimental de Itapetininga. Os primeiros plantios tiveram inicio no ano de 1960 , optando-se pelo plantio do gênero Pinus, em razão das características de solo e clima semelhantes à região de origem dos mesmos, isto é, o Sul dos Estados Unidos da América.

O governo paulista incentivou e executou os primeiros plantios de Pinus nesta região. No ano de 1963, promoveu o Primeiro Encontro Regional de Silvicultura, na Estação Experimental de Itapetininga, com a presença de diversas autoridades e políticos cujo objetivo era mostrar os primeiros resultados obtidos com a nova cultura.

Posteriormente, por iniciativa do Governo Federal, no ano de 1965, pôs-se em prática a política de incentivos fiscais onde era facultado aos devedores com o fisco, aplicar em reflorestamento parte destes recursos devidos. Com isso, dadas as peculiaridades desta região, ela foi contemplada com significativos plantios florestais. O baixo custo da terra e as grandes extensões necessárias para a instalação dos reflorestamentos, aliados às condições bioclimáticas favoráveis ao desenvolvimento dos Pinus subtropicais, levaram à uma concentração da atividade na região sudoeste do Estado de São Paulo. Hoje, estes plantios de Pinus, representam cerca de $44,3 \%$ do total reflorestado no Estado de São Paulo.

O longo prazo de maturação requerido para este investimento levou, mais uma vez, a buscar nas pesquisas, formas de auferir renda com a exploração 
da espécie. Uma aiternativa utilizada foi a extração da resina, copiada do que se fazia no Sul dos Estados Unidos da América, local de origem da espécie, e realizada de forma extrativista, semelhante à extração do látex na Amazônia brasileira.

A resina é conhecida e utilizada desde a pré-história, com as mais diversas finalidades. A atividade, em si, pouco progrediu através dos tempos, não obstante seus derivados serem amplamente utilizados pela sociedade, uma vez que abrangem desde tintas, vernizes e colas até desinfetantes e chicletes.

No Brasil, as pesquisas se direcionaram principalmente para o rendimento por área, havendo progressos importantes com relação ao melhoramento de espécies produtoras, técnicas de exploração e beneficiamento. Porém, quase nenhuma importância foi dada a mão-de-obra, apesar de ser atividade altamente dependente da força de trabalho humano. Nos paises onde a mão-de-obra é cara, não se realiza a extração em árvores vivas, utilizando-se de preferência o tall-oil, um subproduto da produção de celulose.

A primeira vista, o trabalhador da resinagem pode ser confundido com o bóia fria, porém, quando se observa mais acuradamente verificam-se diferenças fundamentais. O trabalhador da resinagem tem contrato em carteira, como tarefeiro rural, trabalhando o ano inteiro e recebendo por produção, de acordo com o tipo de atividade dentro do processo de trabalho: o estriador ${ }^{1}$, ganha por número de estrias feitas diariamente, o coletor $^{2}$ por tambor coletado, o revisor ${ }^{3}$ ganha por dia trabalhado, etc., havendo portanto um certo nível de especialização na atividade, como veremos no capítulo referente ao processo de trabalho.

Até alguns anos atrás, o trabalhador da resina, como outros empregados rurais que ganhavam por produção, costumava levar a família para

1 Trabalhador que com ferramenta apropriada faz a estria na casca da árvore para que a resina escoe.

2 Trabalhador que recolhe a resina dos saquinhos das árvores e coloca nos tambores apropriados.

${ }^{3}$ Trabalhador que substitui os saquinhos danificados durante a coleta da resina. 
ajudar no trabalho. Ele aumentava, desta forma, com o trabalho da mulher e dos filhos a produção e, portanto, a renda. Com isto, as crianças moradoras de acampamento não costumavam freqüentar a escola. Isto ocorria inclusive em áreas sob dominio do Estado, cujos representantes alegavam não ter responsabilidade por esta prática, uma vez que a atividade era realizada por terceiros, que alugavam a floresta do Estado para a extração da goma resina.

Recentemente, houve intensificação na fiscalização, causada pelas denuncias de órgãos da imprensa sobre o trabalho de menores na zona rural, fazendo com que essa prática acabasse na maioria dos acampamentos, sendo então rigorosamente proibida nas áreas arrendadas do Estado. Porém, nos casos em que o pai e a mãe trabalham, as crianças muitas vezes continuavam não freqüentando a escola por ter de cuidar dos irmãos menores e da "casa". No acampamento estudado isto foi modificado no ano de 1999, por iniciativa da professoras.

A "casa", nos acampamentos atuais, costuma ser feita de madeira com dois ou três cômodos. Porém até pouco tempo atrás, ela podia ser confeccionada utilizando embalagens tipo longa vida, ou lona plástica escura. Até hoje, os acampamentos se localizam próximos de rios, ribeirões ou açudes, pois é aí que se lava a roupa e a louça, e é daí que provem a água para o banho e para limpeza, sendo que a água para beber e cozinhar é proveniente de poços.

O esgotamento da fonte do produto extraido faz com que se procurem outras regiões, onde haja ocorrência desse recurso. Isto começa a acontecer com a resinagem na Região estudada, onde os reflorestamentos com Pinus elliottii começam a ser substituidos e os empresários estão começando a se transferir para o Triângulo Mineiro e Norte e Nordeste do Paraná e até Estados da Região Sul, onde os reflorestamentos com Pinus ainda abundam.

Nos catorze anos trabalhando e morando na Estação Experimental de Itapetininga, onde há exploração de resina, fomos observando algumas particularidades dos moradores do acampamento, que os diferenciavam dos outros moradores. 
Viamos que apesar de mudarem as pessoas, em função de contratos ou de busca por melhores ganhos financeiros, permanecia o mesmo perfil do trabalhador e de sua família. As famílias, da noite para o dia, se mudavam para outros acampamentos em outras cidades, mudando não só de local de moradia, mas de patrão: no inicio da resinagem, no final dos anos 70 e inicio dos 80 , era comum empresários mandarem caminhão, à noite, nos acampamentos de outros empresários e oferecerem um valor um pouco maior por tarefa. Nessa época, pessoas que sabiam trabalhar na resinagem eram disputadas.

Observávamos as crianças acompanhando os pais no trabalho, com prejuízo da escola. E quase sempre, os pais alegavam que não adiantava matricular os filhos na escola, pois na maior parte dos acampamentos não havia escola por perto. Mesmo porque, colocá-los na escola era só para perder tempo, pois antes que aprendesse qualquer coisa a família já estava outra vez de mudança. Crianças muito pequenas iam com os pais para a lida e, muitas vezes, bebês de poucos meses, ficavam em caixas de papelão enquanto os pais trabalhavam.

Victor (1977) fazendo uma avaliação dos 10 anos de incentivos ao reflorestamento, reproduzia uma noticia publicada no "Diário de São Paulo" de 24/3/72, onde descrevia os benefícios do reflorestamento no Brasil, afirmando entre outros que "... Como João, muitos outros jovens encontram condições de trabalho junto com seus pais e irmãos, melhorando o nivel de rendimento e, consequentemente, da vida, de toda a família. ...". O que revela o costume de, na zona rural as crianças ajudarem os pais nas tarefas, e como, na década de 70, isto era aceito.

Ao mesmo tempo em que as cláusulas dos contratos firmados entre 0 Instituto Florestal e os empresários visavam proteger a floresta e evitar prejuízos para o Estado, elas permitiam que os acampamentos fossem provisórios, sem exigir um mínimo de condições de habitação. Hoje a fiscalização sanitária passou a fazer vistorias e impor padrões e o Instituto Florestal realiza fiscalização quanto às técnicas de resinagem, visando proteger o seu patrimônio. 
Tudo isto nos motivou a tentar entender melhor a atividade, os seus processos e as pessoas envolvidas. 


\section{OBJETIVOS}

O objetivo deste trabalho é buscar um entendimento e a importância da atividade resineira na Mesorregião de Itapetininga, SP. Para isto julgamos necessário conhecer a atividade do ponto de vista do trabalhador que a exerce, das suas condições de vida e das relações trabalhistas presentes na atividade.

Para atingir este objetivo foram estabelecidos os seguintes objetivos específicos:

Analisar o processo de trabalho na extração da resina, e qual a participação do menor trabalhador ao longo do tempo;

Analisar a ação do Estado frente ao trabalho do menor na resinagem;

Analisar a exploração da resina via contratos/leilões, e os cuidados desses contratos com: preservação da área, árvores produtoras, e com 0 trabalhador e sua familia. 
Capítulo 1

\section{A REGIÃO E SUAS CARACTERÍSTICAS}

A Região estudada é chamada, pela Fundação do Instituto Brasileiro de Geografia e Estatística (FIBGE, 1991), de Mesorregião de Itapetininga e compreende as Microrregiões de: Itapeva, com 9 municípios; Itapetininga, com 3 municípios; Tatuí, com 7 municípios e Capão Bonito com 6 municípios, como podese verificar na Figura 1

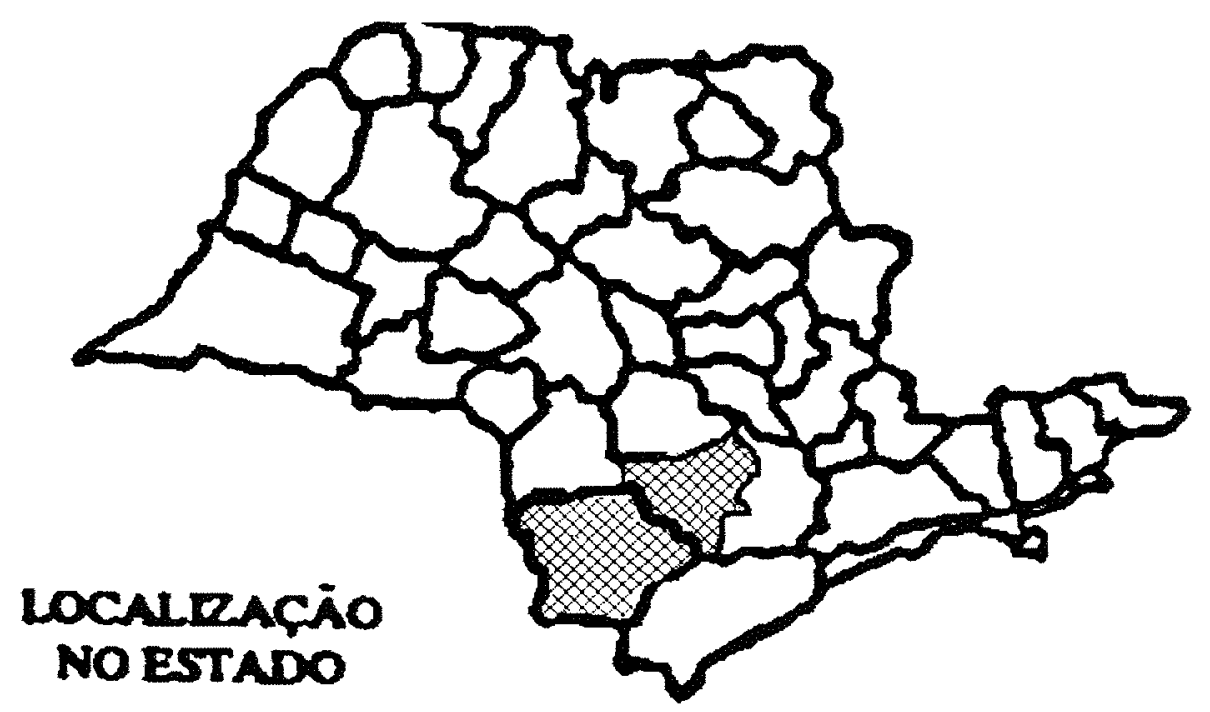

Figura 1: Localização da Mesorregião de Itapetininga - SP 
Algumas características demográficas da Mesorregião são apresentadas na Tabela 1.

Tabela 1 : Características da Mesorregião de Itapetininga

\begin{tabular}{|l|r|}
\hline \multicolumn{1}{|c|}{ CARACTERÍSTICA } & \multicolumn{1}{c|}{ DIMENSÃO } \\
\hline Área & $18.030 \mathrm{~km}^{2}$ \\
\hline População & 642.995 habitantes \\
\hline Densidade demográfica & $35,66 \mathrm{hab} . / \mathrm{km}^{2}$ \\
\hline
\end{tabular}

IBGE, 1991

Uma avaliação feita pela Secretaria de Economia e Planejamento em 1990, previa o desenvolvimento desta Mesorregião alavancada pela agropecuária e agroindústria, baseada na implantação de importantes empreendimentos agropecuários: um projeto de citricultura envolvendo a implantação de uma fábrica de suco de laranja, um projeto agropecuário de engorda de bovinos e alguns matadouros de frango fomentando a parceria na engorda, etc. atraídos por preços relativamente baixos de terra e mão-de-obra abundante e barata.

O Levantamento Censitário de Unidades de Produção Agrícola do Estado de São Paulo - LUPA, Pino et al. (1997) estima a área rural total da Mesorregião em $13.372,06 \mathrm{~km}^{2}$, com a seguinte ocupação do solo em hectares, como mostrado na Tabela 2.

Tabela 2: Ocupação do solo da Mesorregião de Itapetininga e do Estado de São Paulo

\begin{tabular}{|l|r|r|r|r|}
\hline \multicolumn{1}{|c|}{ Ocupação } & $\begin{array}{c}\text { Mesorregião de } \\
\text { Itapetininga } \\
\text { (ha) }\end{array}$ & $\begin{array}{c}\text { \% de ocupação } \\
\text { em relação à } \\
\text { Mesorregião }\end{array}$ & $\begin{array}{c}\text { Estado de São } \\
\text { Paulo (ha) }\end{array}$ & $\begin{array}{c}\text { \%o da } \\
\text { Mesorregião } \\
\text { em relação } \\
\text { ao Estado }\end{array}$ \\
\hline Cultura perene & $15.137,20$ & 1,23 & $1.332 .694,10$ & 1,13 \\
\hline Cultura semi perene & $41.416,70$ & 3,35 & $2.948 .106,20$ & 1,40 \\
\hline Cultura anual & $175.509,10$ & 14,20 & $1.671 .048,50$ & 0,92 \\
\hline Pastagem & $662.615,30$ & 53,63 & $10.274 .801,20$ & 6,44 \\
\hline Reflorestamento & $165.329,40$ & 13,38 & $812.182,80$ & 20,35 \\
\hline Vegetação natural & $175.620,80$ & 14,21 & $1.954 .150,50$ & 8,99 \\
\hline Total & $1.235 .628,50$ & 100 & $18.992 .983,30$ & 6,50 \\
\hline
\end{tabular}

Elaborado a partir de Pino et al., 1997 
Os principais produtos regionais são a batata, o feijão e o milho dentre os anuais e os citros e as frutas dentre os perenes e semi perenes. Embora seja a principal produtora de batatas do Estado de São Paulo e a $11^{\text {a }}$ produtora rural do Estado, apresenta uma produtividade por hectare inferior à média estadual. A área classificada como pastagens ocupa uma grande extensão territorial, mas a pecuária na Mesorregião apresenta baixa produtividade, com uma média regional de 1,08 cabeças/ha, enquanto a média estadual é de 1,24 cabeças/ha.

De acordo com Kronka (1993), na Região Administrativa de Sorocaba, que abrange a Mesorregião de Itapetininga, do total de propriedades rurais existentes, $82,1 \%$ têm área de até 100 ha, sendo que o reflorestamento está concentrado nas médias e grandes propriedades.

A Tabela 3, obtida dos dados do Censo Demográfico do IBGE (1991), mostra o tempo de estudo da população da Mesorregião.

Tabela 3: Tempo de estudo na Mesorregião de Itapetininga, para pessoas com mais de 10 anos de idade

\begin{tabular}{|l|r|r|}
\hline \multicolumn{3}{|c|}{ ANOS DE ESTUDO } \\
\hline 0 a 1 anos & 72.706 & $14,74 \%$ \\
\hline 1 a 3 anos & 149.637 & $30,33 \%$ \\
\hline 4 a 7 anos & 177.760 & $36,03 \%$ \\
\hline 8 a 10 anos & 42.991 & $8,71 \%$ \\
\hline 11 a 14 anos & 38.306 & $7,77 \%$ \\
\hline 15 anos ou mais & 11.750 & $2,38 \%$ \\
\hline Não determinados & 157 & $0,03 \%$ \\
\hline Total & $\mathbf{4 9 3 . 3 0 7}$ & $\mathbf{1 0 0} \%$ \\
\hline
\end{tabular}

Fonte: IBGE, 1991

A maior parte das escolas localizadas na zona rural na Mesorregião oferecia até a $3^{a}$ série do ensino fundamental. A Tabela 4 revela que $45,07 \%$ da população maior que 10 anos de idade freqüentaram a escola durante apenas 3 anos. Pode-se supor daí que a maioria desses casos se refere aos alunos da zona rural que abandonariam os estudos no momento em que teriam de continuá-los na cidade. 
Apesar da Prefeitura fornecer transporte escolar gratuito para escolares da zona rural, não podemos esquecer que, ao redor de 9 ou 10 anos, a criança já tem idade suficiente para ajudar a familia nas tarefas, sob supervisão dos pais, entretanto é considerada por estes, pequena para ir sozinha à cidade estudar, o que implica em, geralmente, esperar o ônibus na estrada e descer próximo à escola, freqüentemente sem adultos para recebe-la e acompanhá-la até sua porta. Atualmente ocorre a separação dos irmãos maiores, em escolas distintas, não havendo assim quem olhe os pequenos.

$$
\text { Quanto às características edafo-climáticas, Nogueira }
$$
mencionava que o naturalista Hoehne, indo de São Paulo para o Paraná em 1928, apontou o contraste dos campos que surgem para além de Sorocaba com os que the ficam para trás. Diz ele:

"Para quem conhece a flora e a fitofisionomia dos arredores de São Paulo, a viagem até as imediações de Sorocaba, pouca ou nenhuma novidade oferece....Além de Sorocaba, começam a aparecer campos naturais, que se distinguem bem desses outros, pela sua composição especifica e fisionomia"( $p .31)$

O mesmo Autor, ao estudar a Região na década de 50, observava que os solos estavam erodidos, desgastados pelo mau uso desde o inicio da colonização e cobertos de pastagens de baixo rendimento. Eram solos cujo aproveitamento só seria possivel com o uso de corretivos e fertilizantes. Seriam ideais para agriculturas anuais e facilmente conserváveis com a prática de terraceamento. Outros solos apareciam em manchas e tinham importância secundária.

Para Golfari (1978), as Regiões de Itapetininga e Itararé situam-se na "região bioclimática" 4: Submontano, úmido com chuvas uniformes, apresentando como tipo de vegetação: floresta e campos", compreendendo o

\footnotetext{
${ }^{4}$ Região bioclimática: Tipo de clima e vegetação
} 
planalto centro leste do Paraná e sudoeste de São Paulo, com altitudes variando de 600 a $1.100 \mathrm{~m}$, com vegetação natural de floresta pluvial e campos submontanos, clima submontano ou temperado úmido, temperatura média anual de $16-19{ }^{\circ} \mathrm{C}$, com geadas pouco freqüentes, precipitações médias anuais de 1.100 a $1.400 \mathrm{~mm}$ uniformemente distribuidas e sem deficiência hídrica. O autor afirma ainda, que essas características tornam a região propícia ao reflorestamento com pinus subtropicais: Pinus elliottii e Pinus taeda.

Conforme o IBGE (1996), os solos da Região são: a) principalmente Solos com Horizonte B Latossólico que, em geral, são fortemente ácidos e com baixa reserva de elementos nutritivos para as plantas e b) Solos com Horizonte $B$ Textural, que apresentam grandes variações em suas características físicas, químicas e morfológicas, podendo apresentar propriedades favoráveis ao desenvolvimento de plantas em alguns locais, enquanto em outros, têm limitações para uso agrícola. Quanto à potencialidade agrícola da região, O IBGE (1996), classifica em: regular, com deficiência de nutrientes e teores elevados de alumínio; restrita, com fortes declives, susceptibilidade à erosão, deficiência de drenagem e de nutrientes e teores elevados de alumínio; e boa, praticamente sem limitação, em manchas.

No mapa de Levantamento de Aptidão Florestal das Terras as terras desta região são classificadas predominantemente nas categorias $C, D$ e manchas de $A$, como podemos ver na Figura 2, sendo que essas categorias se referem a:

A - compreende desde terras planas e férteis, apropriadas para agricultura, até terras de relevo ondulado, com no máximo $20 \%$ de declive, ou solos de textura mais arenosa e com problemas de fertilidade, apropriados para culturas perenes e pastagens;

C - compreende as terras acidentadas, com declives de $20-40 \%$ e aquelas com sérios problemas de fertilidade, sendo indicadas predominantemente para reflorestamento e pastagem; 
D - compreende solos bastante acidentados, com declives acima de $40 \%$, ou terras com seríssimos problemas relativos à profundidade, fertilidade ou pedregosidade, sendo áreas indicadas para reflorestamento e abrigo da fauna e da flora, com limitações até mesmo para reflorestamento.

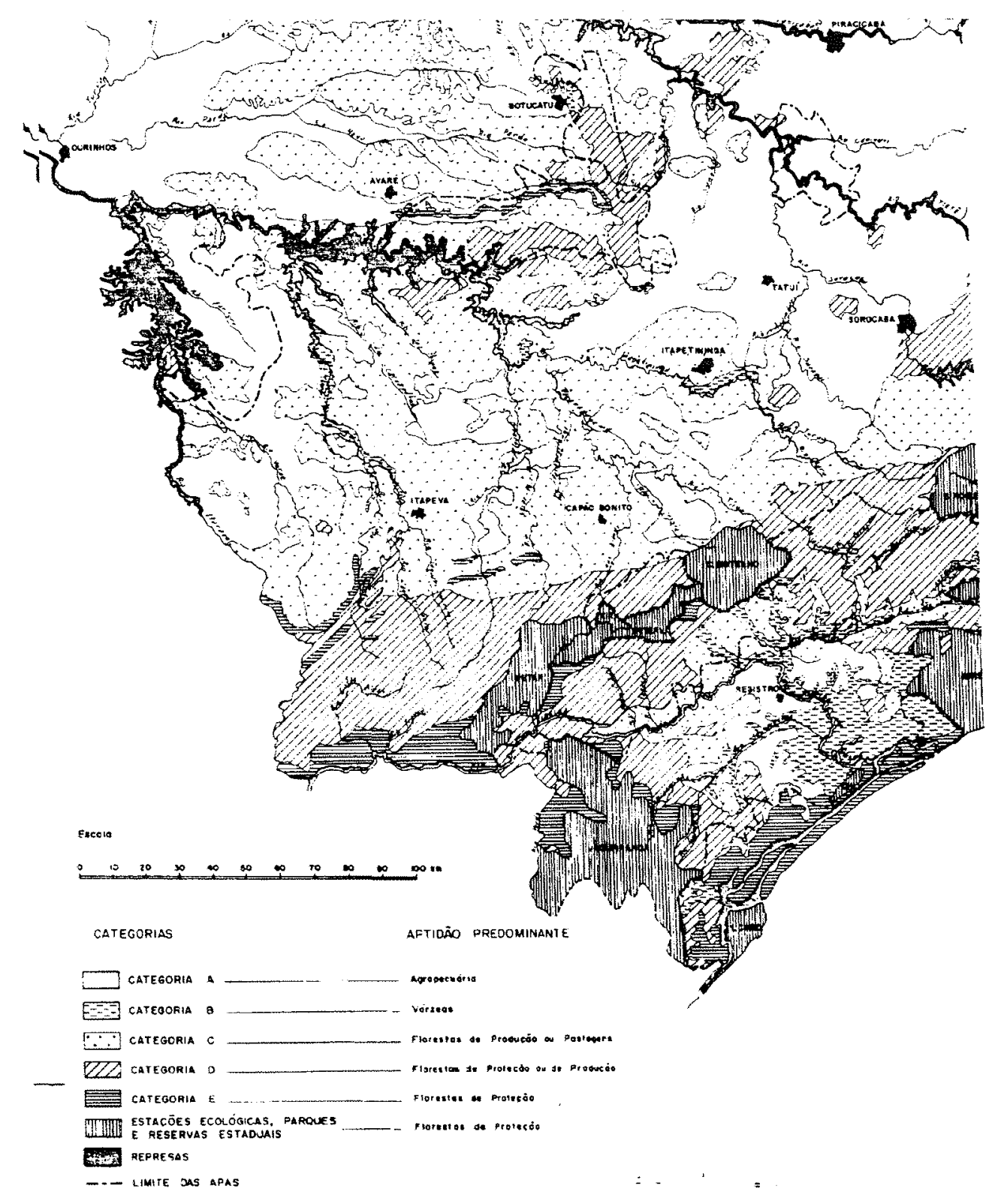

Figura 2: Levantamento de aptidão florestal das terras (FF, 1993) 


\section{Perfil Histórico}

A historia dos municípios que compõem as regiões de Itapetininga e Itapeva está ligada à colonização do sul do Brasil. Nogueira (1962) descreve como até o século XVIII a região era ponto estratégico entre a criação de eqüinos, muares e bovinos no sul e as novas necessidades de transporte e abastecimento surgidas, a princípio, pela mineração no interior da colônia e depois pela lavoura canavieira no interior de São Paulo. Neste contexto as cidades de Itapetininga e Itapeva, entre outras, surgem como Pouso de Tropeiros. O geógrafo Pierre Deffontaines, citado por Nogueira (1962), comenta:

"No Brasil meridional, existia uma estrada de gado de um tipo particular, era o caminho das mulas, a estrada mulada. A maior parte das mulas e burros que serviam ao transporte do Brasil litoral e central, não eram produzidos no lugar, provinham dos grandes pastos do sul e sobretudo do território das Missões e do Uruguai. Eles se detinham em pousos ou invernadas (Apiaí, São Miguel Arcanjo, Itapetininga) e alcançavam o centro das feiras de burros em Sorocaba, que se tornou uma das principais cidades do Estado de São Paulo." (p. 45)

No inicio do processo de colonização a população da Região era constituída de brancos (fazendeiros, posseiros e grileiros) e caboclos. Na primeira metade do século XIX, vamos encontrar na região as seguintes características: desenvolvimento do setor terciário da economia, inicio do processo de divisão de terras e a migração dos brancos: posseiros e grileiros (Secretaria de Economia e Planejamento, 1991).

Saint-Hilaire, em 1820, vindo de Sorocaba para Itapetininga, descrevia que "...a região não é deserta, mas percebe-se que se abandonam distritos ricos e florescentes, onde é cultivada a cana-de-açúcar, e que se entra numa região miserável e pouco civilizada" (p. 266). O autor chega a afirmar que desde que se encontrava no Brasil "... não presenciara em parte alguma tamanha pobreza" (p. 266), e Nogueira (1962), comentava que percorrendo o Município em 
diferentes direções na zona rural tinha a impressão que nada havia mudado. Para a Secretaria de Economia e Planejamento (1991) a Região ganha importância no momento em que aparece exatamente no meio do caminho entre o ouro das Minas Gerais e o gado do cone sul da América Latina.

Segundo Nogueira (1962), fatores como o avanço da população para - Oeste, o apogeu do comércio de animais e o desenvolvimento, em âmbito local, de uma agricultura comercial: inicialmente de cana de açúcar e mais tarde do algodão herbáceo, fizeram com que a partir do segundo quarto do século XIX, o município de Itapetininga passasse por uma série de desmembramentos, de modo que no final daquele século já estavam definidos os limites que conserva até hoje.

Em 1895 a ferrovia chega à Itapetininga. A cidade se torna ponta de linha, o que vem intensificar temporariamente suas atividades econômicas tradicionais: ela passa a ser a conexão entre o novo meio de transporte e as tropas arreadas provenientes do Paraná, ou de diferentes pontos do Estado de São Paulo, ao mesmo tempo que para aí se transferem muitas atividades próprias do comércio de animais que antes se concentravam em Sorocaba. A chegada da Estrada de Ferro, aliada ao aparecimento de instituições sociais e culturais, hospitais, escolas e clubes, favoreceram o desenvolvimento urbano da Região. Quando a Estrada de Ferro se estendeu até o Paraná, surgiu o epiteto de Ramal da fome como menciona Victor (1977), pois Itapetininga continuou sendo ponta de linha para o carro restaurante, que daí retornava a cidade de São Paulo.

Para a Secretaria de Economia e Planejamento (1991), no final do século XIX, acentua-se a influência política de Itapetininga, que em 1895 recebe a primeira Escola Normal do interior do Brasil. Esta influência será intensificada até 1930, com o advento do Getulismo. O algodão, produzido em Itapetininga e Sarapuí, torna-se o primeiro produto de exportação e, juntamente com a influência política, coloca a Região em destaque no cenário da província. À população original de brancos, caboclos, mulatos e negros somam-se os estrangeiros que não se integraram à produção cafeeira no Vale do Paraíba. O algodão faz surgir em Itapetininga várias industrias de beneficiamento como as têxteis e as fábricas de 
óleo. O processo de urbanização é acelerado pela introdução da eletricidade, do telefone e serviços de água e esgoto. A afirmação de Itapetininga como centro cultural da região se confirma pela presença de cinemas, emissoras de radio e jornais, sendo que Piza (1924) assim descrevia Itapetininga: "...tem bons hotéis e teatros, sendo dotada de todos os melhoramentos exigidos pelo conforto." 5 (Piza, 1924, p.112).

Após a $2^{a}$. Guerra Mundial, as manipulações políticas, o esgotamento das terras, o surgimento dos fios sintéticos e o setor energético deficitário, contribuíram para a morosidade do progresso da região neste século.

A partir de 1930 , devido a problemas políticos ${ }^{6}$, há uma queda no prestígio político de Itapetininga, que perde a Escola de Odontologia e $05^{\circ}$. Batalhão de Caçadores do Exército. Os moradores mais antigos contam que, na época, Itapetininga ficou estagnada por causa da intolerância do Governo Federal, por ser a terra dos Prestes.

Na década de 60 , principalmente após a revolução de 64 , com a centralização político-administrativa em Brasília, a região foi afetada pelo incentivo a exportação e pela nova política agrícola, que favorece o reflorestamento através das Leis de Incentivos Fiscais.. Victor (1981) citava Lauriston Bicudo que vaticinava de modo otimista sobre o reflorestamento que era praticado nas regiões de terras mais fracas do Estado de São Paulo: "... o outrora chamado "ramal da fome", por exemplo, poderá vir a ser a "estrada da fartura". Haverá um quase nivelamento geral, a partir da riqueza que a industrialização da madeira por certo determinará..." (p. 33), Em 1985 a industria da madeira representava 20,68\% do valor de produção do município de Itapetininga (IBGE,1985)

\footnotetext{
${ }^{5}$ Atualmente Itapetininga não possui teatros e conta com apenas uma sala de cinema.

6 Júlio Prestes de Albuquerque (1882-1946), politico brasileiro natural de Itapetininga, que foi deputado federal em 1919, líder da bancada paulista. Assumiu o Governo de São Paulo em 1927, e em 1930 foi eleito Presidente da Republica, porém não chegou a tomar posse devido à Revolução de outubro deste ano, foi exilado até 1934, não se dedicou mais à política. (Grande Enciclopédia Larousse Cultural, 1988: 4871)
} 


\section{Capitulo 2}

\section{A RESINA}

O Dicionário Aurélio Eletrônico (1995), define resina:

"Verbete: resina

[Do gr. rhetíne, pelo lat. resina.]

S. $f$.

1. Secrecão viscosa que exsuda do caule e de outros órgãos de certas plantas, e que contém substâncias odoríferas, anti-sépticas, etc. as quais cicatrizam rapidamente qualquer ferida em tais órqãos, assumindo aspecto vitreo.'

2. Produto extraído da resina (1).

3. P. ext. Designação comum a certos produtos sintéticos de características análogas às da resina (1). [Cf. rezina e rizina.] ..." (Dicionário Aurélio Eletrônico, v. 1.5)

Para o Dicionário eletrônico Michaelis, (1996) resina é:

\footnotetext{
7 Grifo do autor
} 
"s. f. 1. Matéria oleosa e inflamável que, por incisão, se extrai de certas árvores..." (DIC - Dicionário eletrônico Michaelis, v. 4.00)

Ferri et al. (1969) e Clements (1970) definem as resinas como: substâncias segregadas por várias plantas, encontradas em canais resiníferos, que podem sair através de feridas e têm composição diversificada e complexa. Ocorrem nas folhosas: exemplo típico é o látex extraído da seringueira - Hevea brasiliensis, também em várias espécies de Eucalyptus que exsudam goma quando submetidas a um ferimento. Porém as coníferas, entre elas a Araucaria angustifolia (o pinheiro do Paraná), possuem um teor mais elevado.

Segundo Gurgel Filho (1970), Instituto Florestal (1981), Couto (1983) e Caser et al. (1998) as resinas do gênero Pinus são chamadas oleoresinas e têm como componentes principais o breu e a terebintina. De acordo com Augusto Filho (1994), da destilação das oleoresinas se obtém: $17 \%$ de terebintina, que é a fração volátil e $68 \%$ de breu ou colofônia que é a fração sólida.

Durante a fabricação do papel, a partir do Pinus, há a ocorrência do tall-oil, produto derivado da lixívia negra com $30 \%$ de breu, com rendimento de 30 - $40 \mathrm{~kg} / \mathrm{t}$ de celulose. Também é possivel obter alcatrão, uma espécie de breu, no processo de carbonização do Pinus (Berzaghi, 1983; Augusto Filho, 1994). No presente trabalho abordaremos a extração de resina de plantas vivas, do gênero Pinus. A Figura 3 mostra a cadeia produtiva do Pinus, segundo Caser et al. (1998).

Brito e Barrichelo (1978) informam que as oleoresinas possuem maior valor comercial, porque somente estas encontram-se sob pressão, podendo ser extraídas ou exploradas comercialmente. 


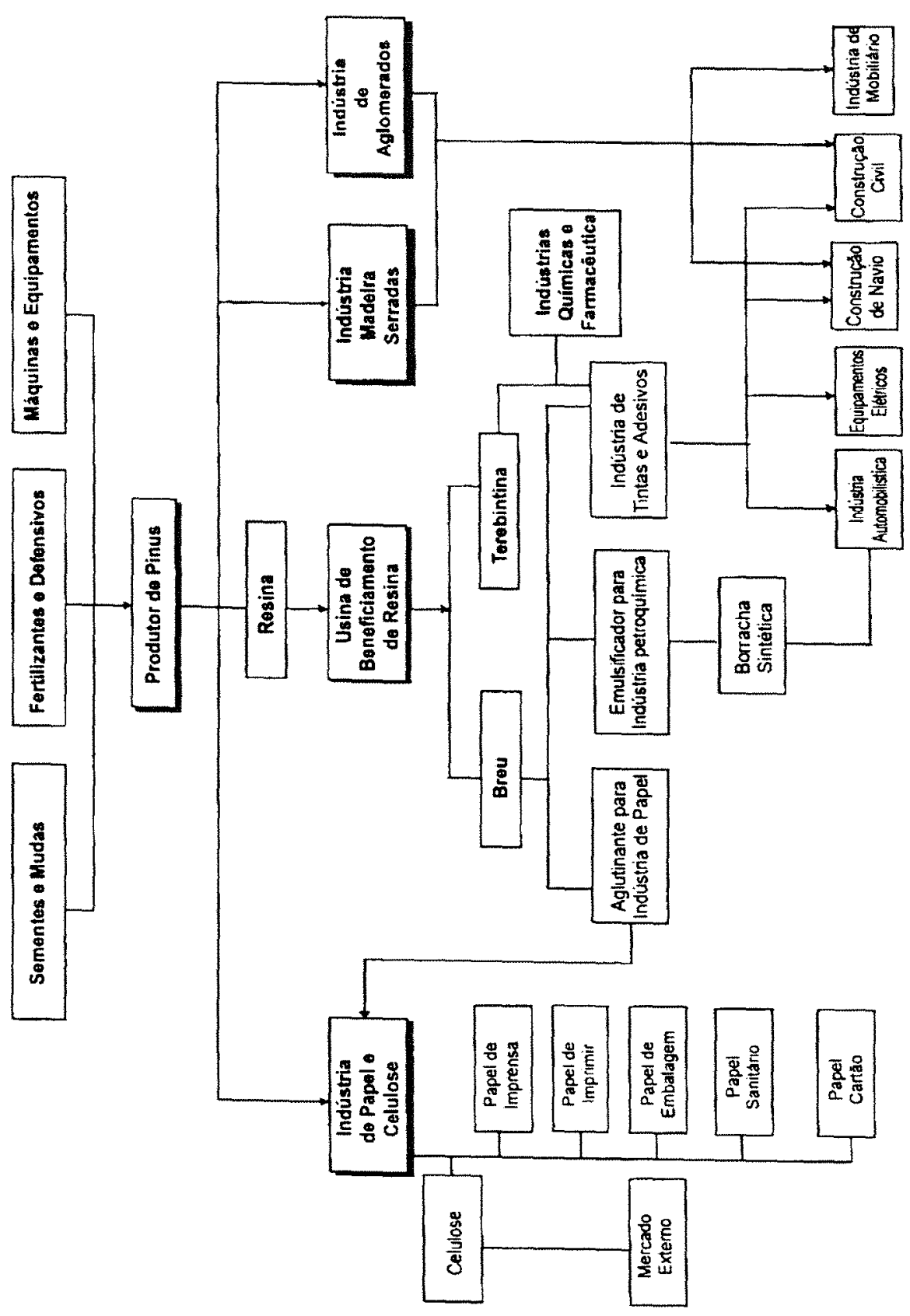

Figura 3: Cadeia produtora do Pinus (Caser, 1998) 
Berzaghi (1967) e Fonseca \& Kageyama (1978) mencionam que as principais espécies produtoras de resinas são Pinus elliottii var. elliottii, Pinus caribaea e Pinus palustris originárias dos Estados Unidos e Pinus pinaster e Pinus sy/vestris provenientes da Europa. Berzaghi (1967), Garnica. et al. (1983) e Caser et al. (1998) afirmam que o Pinus elliottii é a espécie que oferece a mais alta produção de resina, sendo considerado a mais importante, tanto por sua alta produtividade, como por produzir uma resina mais fluida, sem crostas e com alta porcentagem de terebintina de aspectos químicos favoráveis.

Gurgel Filho (1971) e Fonseca \& Kageyama (1978) indicam o Pinus elliottii var. elliottii como espécie com potencial para trabalhos de melhoramento visando à produção de resina.

\section{O gênero Pinus}

Na década de 50, segundo Martins (1991), o Eucalyptus reinava no Estado de São Paulo como fonte de abastecimento de combustivel, carvão vegetal e madeira para dormentes e postes. Em 1925 Navarro de Andrade já havia tentado utilizar eucalipto para fabricar papel porém, havia sido frustrado em função dos elevados preços da maquinaria e direitos alfandegários.

O crescente consumo de madeiras moles, levou ao esgotamento das reservas naturais de pinheiro brasileiro (Araucaria angustifolia) existentes no sul do Brasil, o que, segundo o mesmo autor, acarretou em 1959 um novo período florestal: a Era do Pinus, pois a araucária por ser uma espécie exigente, tornava o seu reflorestamento extremamente problemático e oneroso. A industria da celulose requeria na década de 60 , uma área reflorestada, no Estado de São Paulo, da ordem de 450.000 ha, segundo Martins (1991).

Buscando alternativas para a araucária o Serviço Florestal do Estado, atual Instituto Florestal, criou as bases técnicas da pinocultura brasileira com a introdução, pesquisas e plantios, em suas Estações Experimentais, de coníferas produtoras de fibras longas e madeira mole, originárias, principalmente, do Sul dos Estados Unidos e da América Central. (Instituto Florestal, 1980; 1994). 
A Lei 5.106 de 02/09/66, concedendo incentivos a empreendimentos florestais, veio tornar o reflorestamento uma atividade altamente atraente no período, de forma que na década de 70 a reserva florestal de propriedade do Estado já atingia o limiar de 60 milhões de coníferas plantadas (Martins \& Lapolla, 1987).

Segundo o Zoneamento Agrícola do Estado de São Paulo (1974) havia, no Estado, 127.050 ha de Pinus, sendo 77.653ha na Região de Sorocaba e destes 58.022 ha em Itapetininga e Itapeva, como pode-se observar na Figura 4.

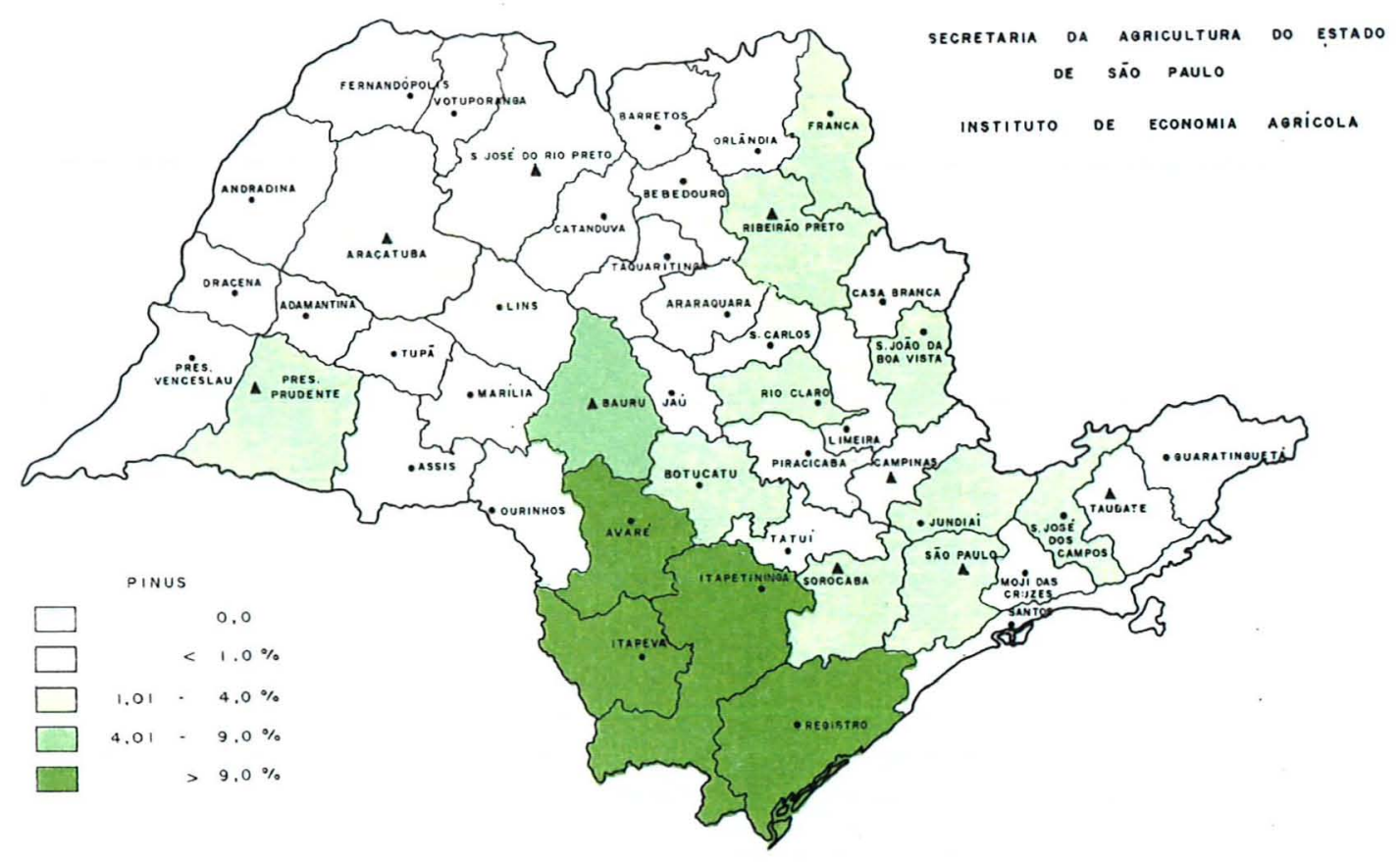

Figura 4: Distribuição do Pinus no Estado de São Paulo (São Paulo, 1974)

Das espécies plantadas no Estado de São Paulo, o Pinus elliottii adaptou-se muito bem à Região Sudoeste do Estado, que apresenta condições edafo-climáticas apropriadas à cultura, tais como: ausência de déficit hídrico e inverno frio, sendo esta espécie indiferente às condições do solo. As espécies 
tropicais, originárias da América Central, os Pinus caribaea, Pinus oocarpa e Pinus kaesiya se adaptaram melhor nas demais Regiões (Golfari, 1978).

O Pinus elliottii var. elliottii é originário da América do Norte sendo considerado por Dorman \& Squillace (1974) uma das espécies mais importantes do Sudeste dos Estados Unidos, onde sua área de ocorrência natural se estende desde a Planície Costeira do Sul da Carolina do Sul até a Flórida central e Sudeste da Louisiana, sendo usada principalmente para a fabricação de celulose, serraria e produção de resina.

O desenvolvimento das pesquisas e técnicas e a evolução dos equipamentos e maquinários fizeram com que a industria do papel e celulose avançasse no sentido de utilizar o Eucalyptus como matéria prima para a fabricação de celulose de alta qualidade e de alto valor competitivo no mercado mundial (Lima, 1996). Este fator originou a expansão dos reflorestamentos com Eucalyptus e a diminuição do plantio com Pinus, uma vez que atualmente o grande reflorestador no Brasil é a industria de papel e celulose (Kronka, 1993).

Em 1995, o consumo de madeira, no Estado de São Paulo, para a produção de papel e celulose foi de $9.012 .892 \mathrm{~m}^{3}$, sendo $79,7 \%$ de eucalipto e 20,3\% de Pinus (Florestar Estatístico, 1995/1996a)

Freitas (1990) previu que com o fim dos incentivos fiscais, determinado pelo Decreto Lei 1.503 de 23/12/76, poderia haver uma carência de madeiras de reflorestamentos, nas Regiões Sul e Sudoeste do Brasil, após a maturação completa dos plantios, uma vez que o ritmo de implantação de florestas, principalmente de coníferas, estava diminuindo consideravelmente.

A produção de celulose que em 1970 era de 386.000 toneladas passou a ser de 1.250 .000 toneladas, em 1992. No mesmo período o reflorestamento de Eucalyptus, matéria prima da celulose, aumentou de 510.000 ha, em 1970, para 610.544,02 ha em 1992 enquanto a área plantada de Pinus, no mesmo período, cresceu de 102.100 ha para 194.054,23 ha. (Kronka, 1993). 
Kronka (1993) analisando a evolução do reflorestamento na Região de Sorocaba, mais especificamente nas sub-regiões de Avaré, Botucatu, Itapetininga e Tatuí, no período compreendido entre 1978 e 1992, observou que enquanto a área plantada de Pinus na região diminuiu muito, aproximadamente $22 \%$, a de Eucalyptus sofreu pequena diminuição, em torno de $3 \%$, como se pode observar no Quadro 4.

Quadro 4: Evolução do reflorestamento com Pinus e Eucalyptus, em área (ha) no período de 1978 a 1992, nas sub-regiōes de Avaré, Botucatu, Itapetininga e Tatuí

\begin{tabular}{|l|r|r|}
\hline \multicolumn{1}{|c|}{ ESPÉCIES } & \multicolumn{1}{|c|}{$\mathbf{1 9 7 8}$} & \multicolumn{1}{|c|}{$\mathbf{1 9 9 1 - 2}$} \\
\hline Pinus & $39.733 \mathrm{ha}$ & $30.879,76$ \\
\hline Eucalyptus & $130.799 \mathrm{ha}$ & $126.117,88$ \\
\hline Total & $170.532 \mathrm{ha}$ & $158.941,89 \mathrm{ha}$ \\
\hline
\end{tabular}

Kronka et al., (1993).

Em 1995, a área reflorestada com Pinus no Estado de São Paulo era da ordem de 186.116 ha, sendo que destes, 125.614 ha se localizam na Região de Sorocaba, que abrange a Mesorregião de Itapetininga (Caser, 1998). Contudo, Kronka et al. (1993) observavam que estas florestas apresentavam um perfil adulto, com $82 \%$ das áreas com idade superior a 15 anos, o que, considerando-se os níveis baixos de plantio da espécie na época, era preocupante a médio prazo. 0 mesmo Autor complementava:

"... especificamente em relação ao pinus elliottii, espécie produtora de resina, para cuja extração se fazem necessárias árvores com amplas copas e diâmetros adequados, resultantes de um correto manejo, verifica-se que $19,5 \%$ de sua área de plantio não foi submetida a nenhum desbaste e 40,7\% sofreram unicamente o $1^{\circ}$. e o $2^{\circ}$. desbastes" (p. 29).

Este fato é relevante quando se considera que, segundo Bucci et al., (1986), a produção de resina é influenciada pelo manejo, sendo superior em áreas que sofreram desbastes e Gurgel Garrido et al., (1994) concluem que o maior ganho ocorre quando o desbaste é seletivo. 
A carência de árvores de Pinus elliottii var. elliottii obrigou a industria de beneficiamento da resina a adaptar as maquinas e equipamentos para beneficiar resinas provenientes de Pinus tropicais, que até o inicio desta década não era explorada por cristalizar-se em contato com o ar, tornando difícil a sua utilização, enquanto a resina proveniente do Pinus elliottii é líquida (Augusto Filho, 1994).

De acordo com o Pino et al. (1997), 39,37\% da superfície reflorestada com Pinus no Estado de São Paulo se concentram na Mesorregião de Itapetininga, totalizando uma área de $53.569,10 \mathrm{ha}$, como se pode observar na Tabela 5.

Tabela 5: Reflorestamento com Pinus e Eucalyptus na Mesorregião de Itapetininga e no Estado de São Paulo

\begin{tabular}{|l|r|r|r|}
\hline & $\begin{array}{c}\text { Área reflorestada } \\
\text { (ha) }\end{array}$ & \multicolumn{1}{|c|}{$\begin{array}{c}\text { Pinus } \\
\text { (ha) }\end{array}$} & \multicolumn{1}{|c|}{$\begin{array}{c}\text { Eucalyptus } \\
\text { (ha) }\end{array}$} \\
\hline Mesorregião de Itapetininga & $165.329,40$ & $53.569,10$ & $105.343,40$ \\
\hline Estado de São Paulo & $812.182,80$ & $136.052,20$ & $679.639,20$ \\
\hline
\end{tabular}

Pino et al.,(1998)

Desta Tabela pode-se perceber que é preocupante 0 futuro da resinagem no Estado, pois apesar de o reflorestamento de Pinus na Mesorregião ocupar posição de destaque em relação ao Estado, esta área ocupada com Pinus representa apenas $4,01 \%$ da área agrícola total da Região.

Em função deste fato, os empresários do setor prevêem que a médio prazo a resinagem deve reduzir-se drasticamente no Estado. Pois a diminuição da área reflorestada com Pinus vem provocando a mudança desta atividade para outras regiões do pais, como o Triângulo Mineiro, MG, Noroeste do Paraná e os outros Estados da Região Sul, chegando até mesmo a países vizinhos onde ainda se encontram grandes áreas reflorestadas com pinus.

\section{A Resinagem}

O conhecimento e a utilização da resina datam do inicio dos tempos, conforme nos mostra Homa (1983), no Quadro 6. 


\section{Quadro 6: Cronologia histórica da resina}

\begin{tabular}{|c|c|c|}
\hline PERÍODO & ANO & ACONTECIMENTOS \\
\hline IDADE DA PEDRA & & Uso de resinas vegetais para colar pedra em ponta de flecha \\
\hline IDADE EGÍPCIA & & $\begin{array}{l}\text { Uso de resinas de Pinus com fins religiosos como o } \\
\text { embalsamamento de múmias. }\end{array}$ \\
\hline SÉCULO III AC & & $\begin{array}{l}\text { Theophrastus escreveu sobre resina de Pinus. Existe registro } \\
\text { desta época com escrita cuneiforme sobre destilação de resina } \\
\text { de Pinus. }\end{array}$ \\
\hline SÉCULO I DC & 78 & $\begin{array}{l}\text { O nome colofônia veio do nome da cidade Colophon que era } \\
\text { um dos pontos de negociação de breu. Registro de uso de } \\
\text { resina de Pinus do Norte da Africa. Egípcios sabiam destilar } \\
\text { resina de Pinus e aproveitar a terebintina. }\end{array}$ \\
\hline SÉCULO VIII & & $\begin{array}{l}\text { Marcus Græcus escreveu sobre a separação de colofônia e } \\
\text { terebintina com retorta. }\end{array}$ \\
\hline SÉCULO XV - XVI & & $\begin{array}{l}\text { Muitos cientistas e químicos estudaram e escreveram sobre a } \\
\text { destilação de resina }\end{array}$ \\
\hline \multirow[t]{2}{*}{ SÉCULO XVII } & 1606 & $\begin{array}{l}\text { Franceses construiram destilador de resina de Pinus em } \\
\text { Massashusetts - EUA. }\end{array}$ \\
\hline & 1637 & $\begin{array}{l}\text { A Suécia exportou } 22.000 \text { ton. de breu e alcatrão (Naval } \\
\text { stores) resultante de destilação seca de madeira }\end{array}$ \\
\hline SÉCULO XVIII & & $\begin{array}{l}\text { A França inicia sua atividade industrial de refinação de resina } \\
\text { aproveitando Pinus plantados para segurar areia das praias }\end{array}$ \\
\hline \multirow[t]{4}{*}{ SÉCULO XIX } & 1834 & Nos EUA começou a utilização de destilado de cobre. \\
\hline & 1868 & Tem inicio a destilação a vapor nos EUA \\
\hline & 1882 & C.F. Dahl inventou o sistema Kraft para fabricação de celulose. \\
\hline & 1894 & W.W. Ashe introduziu a utilização de copos para a resinagem \\
\hline \multirow[t]{7}{*}{ SÉCULO XX } & 1904 & Herty começou a utilizar calhas e copos na resinagem. \\
\hline & 1910 & Inicio da fabricação de Wood resin. \\
\hline & 1920 & Na Finlândia começou a destilação de Tall-oil. \\
\hline & 1931 & É concluído o método olustee de destilação de resinas. \\
\hline & 1935 & $\begin{array}{l}\text { M. Hessenland descobriu a utilização de estimulante (ácido) } \\
\text { na resinagem. }\end{array}$ \\
\hline & 1949 & $\begin{array}{l}\text { Conclusão do método de resinagem que utilizava: ácido } \\
\text { sulfúrico, calhas, recipientes, pregos de cabeça dupla e } \\
\text { aparelho de estriar. }\end{array}$ \\
\hline & 1950 & É iniciada na China a fabricação de colofônia. \\
\hline
\end{tabular}

Homa, 1983

A prática da resinagem data do inicio do século XVII e consiste em fazer cortes ou estrias nas aberturas naturais do lenho para a saida da resina que se encontra sob pressão nos canais resiniferos. Na época, tinha a finalidade de obter a resina, o alcatrão e o breu escuro provenientes das florestas de coníferas do Norte da Europa, para calafetar os barcos de madeira e preservar os cordames 
e os equipamentos em uso na época. A impermeabilização dos navios fenícios era feita com colofônia.

Lieberman \& Goolrick (1979) relatam que em 1705 o Parlamento Britânico ciente das florestas do Novo Mundo expediu o Naval stores act para subsidiar a produção de Naval stores $^{3}$ nas colônias, na esperança de se tornar autosuficiente no produto, essencial para sua poderosa frota, do qual era, até então, dependente da Escandinávia. Atualmente, devido aos altos custos de mão-de-obra, os Estados Unidos e outros países do Primeiro Mundo se utilizam principalmente o tall oil.

O $4^{\circ}$. Encontro sobre goma-resina, realizado em Itapeva/SP, em outubro de 1998, gerou uma Carta, a ser encaminhada às autoridades, órgãos governamentais e entidades de classe, que reflete bem a preocupação dos empresários do setor com o futuro da atividade, principalmente em relação à área plantada e produtividade. A Carta apresenta as seguintes moções e recomendações, da Associação dos Resineiros do Brasil - ARESB, 1998:

$\checkmark$ "designar a ARESB como entidade mediadora entre órgãos governamentais e a comunidade resineira, na discussão dos problemas do setor;

$\checkmark$ recomendar ao IBAMA o estabelecimento de uma política florestal que viabilize economicamente os florestamentos e/ou reflorestamentos com Pinus resineiro melhorado;

$\checkmark$ propor a criação de incentivo especifico para experimentação e pesquisa silvicultural, visando o aumento de produtividade da goma-resina;

$\checkmark$ estimular o estabelecimento de convênios entre empresas, órgãos de pesquisa e universidades para o desenvolvimento e aplicação de novas tecnologias na extração da goma-resina, $e$

\footnotetext{
${ }^{8}$ Naval stores são matérias primas do gênero breu, aguarrás e outros produtos resinosos, suprimentos para navios, especialmente navios de guerra (Santos, 1981).
} 
$\checkmark$ efetuar levantamento do mercado comprador, tanto a nivel nacional como internacional, com vistas a diagnosticar a verdadeira demanda e manter os preços compativeis ao produtor."

Podemos notar por estas reivindicações, que embora os empresários do setor estejam conscientes dos problemas e dificuldades para o futuro da resinagem, devido à diminuição da área plantada com Pinus no Estado de São Paulo, e ao pouco interesse dos reflorestadores em plantar o gênero, não pretendem tomar providencias práticas, como, por exemplo: comprar áreas e plantar florestas de Pinus melhoradas para resina, preferindo transferir as soluções para outros setores: de preferência o governo através da reedição da política de incentivos fiscais. 
Capitulo 3

\section{METODOLOGIA}

Para atingir os objetivos deste trabalho, utilizou-se uma combinação de métodos qualitativos e quantitativos, como preconiza Bliss (1996), quando se conhece muito pouco sobre a população alvo, definindo desta forma as tendências dentro do fenômeno estudado.

Foram empregadas técnicas de coleta de dados usadas em ciências sociais, descritas por Kerlinger (1979) e Gil (1991): entrevistas para determinar o perfil social e as relações trabalhistas. Noronha (1987) também utilizou entrevistas diretas, através de questionário para levantar as caracteristicas socioeconômicas do seringueiro do Acre. Triviños (1987) recomenda que na pesquisa qualitativa seja adotada a entrevista semi- estruturada pois, ao mesmo tempo em que valoriza a presença do investigador, oferece a oportunidade para que o informante tenha a liberdade e espontaneidade necessárias.

As entrevistas foram realizadas porta a porta o que, segundo Bliss (1996), é vantajoso pois permite um controle dos dados obtidos já que o entrevistador pode explicar as questões mais complexas e incluir questões extras a partir de comentários do entrevistado, além de proporcionar a obtenção de dados adicionais de observação. No nosso caso, optamos por realizar as entrevistas nas casas, após o expediente, porque os trabalhadores entrevistados recebem por 
produção, e não queriamos interferir no rendimento diário, interrompendo o seu trabalho.

As informações foram complementadas com os empresários, individualmente, ou em reuniões periódicas da ARESB, que congrega os empresários da resinagem, onde foram anotadas as referências à atividade e aos funcionários, e com o Presidente do Sindicato dos Trabalhadores Rurais onde se buscou principalmente os aspectos relacionados ao regime de trabalho, à legislação e à fiscalização.

Bliss \& Flick (1994) estudando trabalhadores florestais no Alabama, também utilizaram a técnica de entrevistar o sujeito do estudo, complementando com outros envolvidos na industria de produtos florestais, no Sul dos Estados Unidos. Neste caso, as entrevistas com os trabalhadores foram complementadas com conversas com os empresários da ARESB e Pesquisadores do Instituto Florestal, e com os familiares do trabalhador, que não participavam diretamente da atividade, mas residiam na casa.

Nas reuniões da ARESB, foram contatados os empresários do setor, que tomaram conhecimento dos objetivos do trabalho e do conteúdo da entrevista, assim como do compromisso de não divulgar os nomes das empresas ou quaisquer características que pudessem identifica-las dentro no Universo da resinagem.

Triviños (1987) afirma que a pesquisa qualitativa pode usar recursos aleatórios para fixar a amostra, procurando uma representatividade maior dos sujeitos que participarão dos estudos. Partindo deste princípio, foram selecionadas três empresas, que atuam na extração de goma resina na Região estudada, procurando abranger os vários segmentos da atividade:

a) um arrendatário de florestas e exportador de goma resina, atuando em área de propriedade do Instituto Florestal, mantendo os empregados morando em acampamento dentro da área florestal; 
b) um proprietário de reflorestamentos e beneficiador primário de goma resina, atuando neste caso, em área própria e mantendo os empregados morando em colônia, dentro da área florestal;

c) um proprietário e arrendatário de reflorestamentos, beneficiador e processador de resina, atuando em área de propriedade do Instituto Florestal, contratando os empregados em bairro rural próximo à área resinada.

O critério para a seleção procurou levar em conta empresas de vários tamanhos, aliado às condições de alojamento dos seus empregados, sem a preocupação de que o tamanho da amostra representasse estatisticamente a população estudada, e sim de que abrangesse os vários tipos de empresas e de acomodações dos empregados.

Foram encontrados alguns problemas para a realização das entrevistas: em um dos casos houve tentativa de indução por parte de um empresário, pois o encarregado acompanhou o entrevistador em todas as moradias e as respostas às varias questões foram idênticas. Este problema foi contornado pelo entrevistador através de questões extras e observação. Em outro caso os trabalhadores se recusaram a responder as perguntas, enquanto o encarregado não realizou uma reunião comunicando que a realização da entrevista havia sido autorizada pelo empresário.

As entrevistas realizadas nas moradias permitem uma avaliação, por observação simples, das condições de habitação, além de permitir uma conversa informal com os familiares do trabalhador, objetivando obter informações adicionais.

\section{Características das moradias}

Foram enfocadas três situações de moradia: acampamento, colônia e casas em bairros próximos à floresta. 
Acampamento

Acampamentos são acomodações provisórias, localizados na área do reflorestamento alugado ou arrendado para fins de exploração da resina, feitos para durar o período do contrato para a extração da goma resina, que no caso do Instituto Florestal, é de um ano, podendo ser renovado.

Com a intensificação da fiscalização trabalhista e sanitária, os acampamentos atingiram melhores condições sanitárias. Na década de 80 e até o inicio da década de 90, eram comuns os acampamentos de resinagem onde as "casas" eram de plástico preto ou embalagens longa vida.

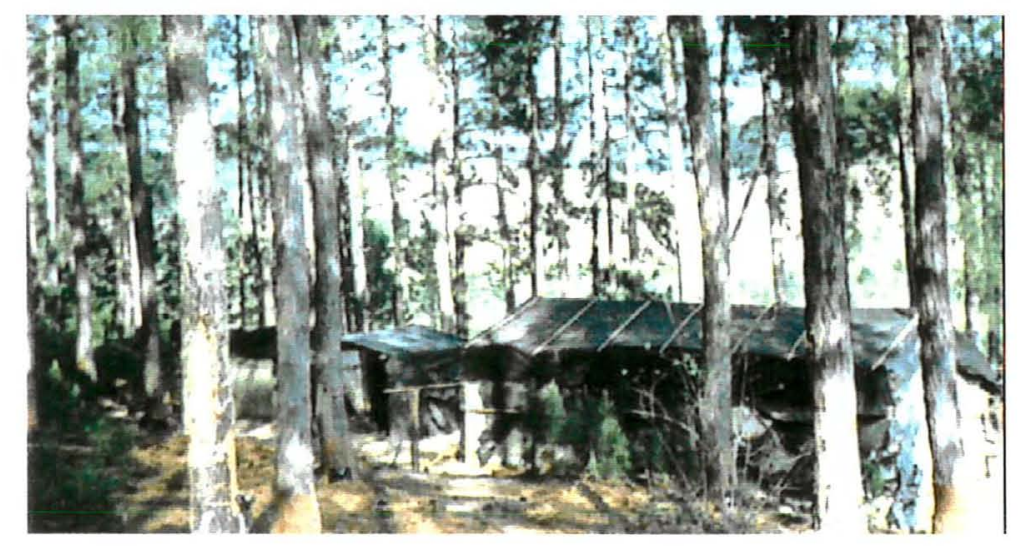

Figura 5: Acampamento de resinagem da década de 80.

Os acampamentos atuais são construídos de tábuas residuais de serrarias, costaneiras, sem nenhum tratamento químico, ou de aspecto construtivo que garantam durabilidade superior a 2 anos. Muitas vezes não há sequer o cuidado de retirar as cascas. As tábuas, ou costaneiras, são pregadas verticalmente, sobrepondo-se umas as outras, para evitar o máximo possível de frestas. São cobertas de telhas de fibrocimento de fina espessura causando com isso desconforto térmico devido as variações de temperatura.

O acampamento estudado consiste de 41 casas de madeira com sala e quarto. Algumas famílias aumentaram o número de cômodos para até 4 , de acordo com o número de moradores. 
As instalações sanitárias consistem de 7 "casinhas", nos fundos do acampamento, servidas de fossa negra, sendo que a água para uso doméstico é proveniente de 4 poços distribuídos nas ruas frontal e central do acampamento. A roupa é lavada no ribeirão que margeia a área. Possui luz elétrica, o que não costuma ser a regra nos acampamentos.

Foram entrevistados 41 trabalhadores no acampamento, um em cada casa, normalmente o chefe da família. Em $60 \%$ das casas moram 3 ou 4 pessoas, em $22,85 \%$ moram mais de 5 pessoas.

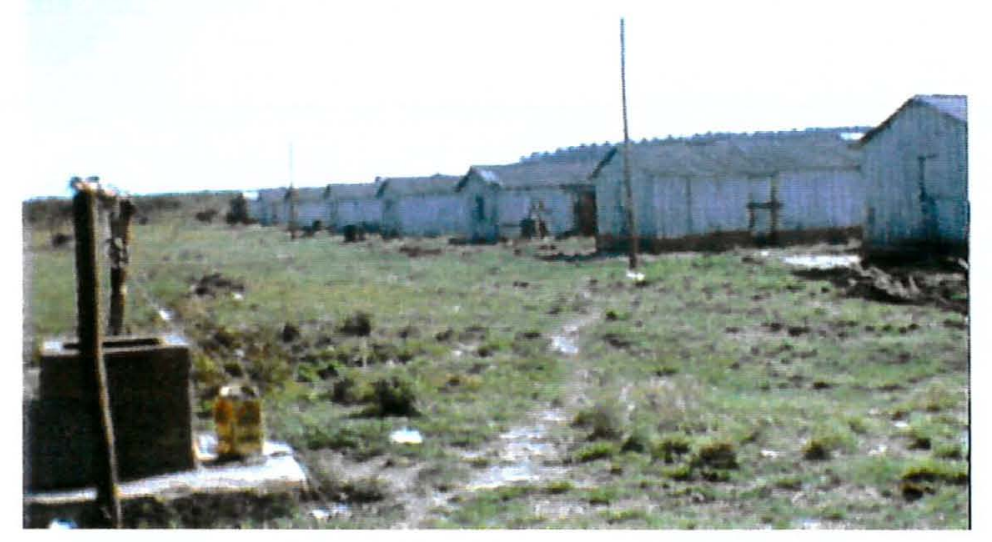

Figura 6: Acampamento de resinagem atual

Condições de moradia semelhantes foram encontradas por Lieberman \& Goolrick (1979) no Sul da Georgia - USA, os autores descrevem como os trabalhadores da industria da resina ("turpentiners") moravam em "cabanas decadentes" em quarteirões no meio da floresta de Pinus em "agrupamentos de cabanas de madeira vermelho desbotados que alojam 15 trabalhadores e suas familias".

Fonseca et al. (1953) estudando os trabalhadores florestais, em três Parques do Instituto Nacional do Pinho, localizados no Paraná, descrevem as habitações, como constituídas de casas de madeira, com 2, 3, 4 e 5 cômodos, algumas adequadas ao número de moradores, outras no entanto pequenas para o numero de pessoas. Em uma casa de 3 cômodos, moravam um casal e 6 menores. 
Descreve também a má conservação das casas, comentando sobre "a naturalidade com que seus moradores aceitam a sua condição ignorando a possibilidade de uma vida melhor sic.." (Fonseca et al, 1953: 24)

O mesmo Autor descreve ainda como a água é tirada de poços, em precárias condições de higiene: sem tampa, com plantas nas paredes e alguns, "inclusive o da casa da administração ... localizado a poucos metros à frente da fossa". As casas são servidas por "fossa negra", sendo que em um dos Parques estudados havia uma fossa para cada grupo de casas.

Essa descrição das condições de vida do trabalhador florestal no Paraná, na década de 50, é muito semelhante às condições encontradas nos acampamentos de resinagem no Estado de São Paulo, nos dias atuais.

Segundo o Boletim Informativo ARESB (1992), em outubro de 1992, foi realizada em Itapetininga uma reunião com a presença da Federação dos Trabalhadores na Agricultura no Estado de São Paulo - FETAESP, Federação da Agricultura do Estado de São Paulo - FAESP e da Associação Paulista de Reflorestamento - APRA, para analisar as reivindicações da classe dos trabalhadores, dentre as quais se incluiam "... 8 - Moradia de alvenaria com água, luz, etc., gratuita. 9 - Cesta básica, gratuita, com bolacha, bacon, etc.".

Estas reivindicações dos trabalhadores geraram o Acórdão SDC $\mathrm{N}^{\circ}$. 0229/94-A, que diz na cláusula 25": "fornecimento de moradia: a moradia fornecida pelo empregador aos trabalhadores deverá ser construida de alvenaria e conter, no mínimo luz elétrica, água encanada e instalação sanitária interna, sem ônus para estes". Entretanto poucos empresários chegaram a cumprir esta norma.

\section{Colônia}

Este é um caso em que a empresa resina em área própria. Os trabalhadores moram em colônia, situada na área florestal, com casas de alvenaria, servidas de água encanada, luz elétrica e esgoto doméstico. 
A colônia estudada consta de 21 casas de alvenaria, com 4 cômodos e banheiro anexo, na propriedade rural, onde se localiza o reflorestamento. Foi entrevistado um trabalhador em cada casa, normalmente o chefe da família.

Verificou-se que $85,71 \%$ das casas nesta colônia têm esgoto, água encanada e luz elétrica. O número de moradores por casa é de 2 a 3 pessoas $(61,90 \%)$ e em $23,81 \%$ das casas vivem mais de 5 pessoas.

\section{Bairro}

Trata-se de uma situação em que a firma, está retirando o acampamento da floresta arrendada e contratou moradores de um bairro rural, próximo à área que está sendo explorada, transportando esses trabalhadores até o local de trabalho; ficando apenas $19,23 \%$ dos empregados no antigo acampamento, sendo portanto uma situação mista.

Neste bairro 22 casas eram habitadas por trabalhadores da resinagem. Destas apenas $42,31 \%$ são servidas de esgoto, $69,23 \%$ de água encanada e $73,08 \%$ de luz elétrica.

O número de moradores por casa é de 3 a $4(53,84 \%)$, sendo que em $23,08 \%$ das casas moram mais de 5 pessoas. Foram entrevistados 22 trabalhadores que moravam no bairro e 4 que ainda se alojavam no acampamento, no momento da entrevista.

A maioria das empresas resineiras instala seus trabalhadores em acampamentos: casas temporárias de madeira, nas áreas de exploração. Esses acampamentos têm a duração do período de aluguel da floresta, que é de uma safra ou seja 1 ano, podendo ser renovado.

Considerando-se que grande parte da área explorada para resinagem no Estado de São Paulo, pertence ao Instituto Florestal que atualmente proíbe a instalação de novos acampamentos em suas áreas, percebe-se que a curto prazo os empresários deverão encontrar outras alternativas para a acomodação dos 
empregados e acabar com o sistema de acampamentos. Nesses casos, os empresários que alugam essas áreas têm empregado moradores de vilas e bairros rurais próximos.

Há entre os empresários algumas previsões quanto a tendência de moradia dos empregados da resina no futuro: alguns pensam em contratar empregados na cidade e transportá-los para o local da resinagem. Porém isto é visto com reservas por outros, pois a concorrência com os bóias frias, em determinadas épocas do ano, vai encarecer a mão-de-obra. Há empresários que preferem optar por comprar áreas em bairros na cidade ou próximo, para construir casas de alvenaria, criando assim colônias para instalar seus empregados, porém isto só será economicamente viável se o período de contrato for prolongado. 


\section{O PROCESSO DE TRABALHO NA RESINAGEM}

O processo de trabalho na resinagem teve uma evolução lenta através dos tempos e sempre priorizando a produção em detrimento da árvore, da floresta e até recentemente do trabalhador e sua produtividade.

Berzaghi (1983), relata como as primeiras tentativas de extrair goma resina das plantas as conduziam ao perecimento, pois o processo consistia em abrir um buraco na base do tronco, ao nivel do solo, que serviria de caixa de depósito, para onde escorria e era coletada a goma resina que exsudava da parte ferida, originada da remoção da casca e parte do alburno imediatamente acima do buraco. Posteriormente, segundo Lieberman \& Goolrick, (1979), em 1901 o professor de química da Universidade da Georgia, Charles H. Herty, desenvolveu um método que não provocava grandes danos a árvore, onde apenas a casca era removida e a goma resina coletada em canaletas metálicas escorria para um recipiente coletor.

Os primeiros trabalhos experimentais com resinagem de Pinus elliottii var. elliottii, no Brasil, se iniciaram em 1968, no Instituto Florestal, que entendia ser este uma importante fonte de produtos resinosos, com um grande valor econômico (Gurgel Filho et al., 1967). Baena (1994) corrobora que vários estudos foram desenvolvidos pelo Instituto Florestal, sendo seus resultados utilizados por empresas e proprietários florestais. 
Gurgel Filho, em visita à região florestal sul dos Estados Unidos, se interessou especialmente pelas atividades do "Naval Stores Conservation Program ${ }^{\prime \prime}$, tendo em vista que as florestas de Pinus elliottii var. elliottii implantadas na década de 60 estavam sendo subaproveitadas, porque apenas a madeira era retirada. O manual de resinagem "Métodos da moderna resinagem", publicado pelo Instituto Florestal em 1970, era a tradução de um manual de resinagem existente no Serviço Florestal Norte Americano desde 1965, tendo sido durante muitos anos um referencial dos passos de extração da goma resina, no Brasil (Gurgel Filho et al., 1967).

A resinagem comercial iniciou-se em Buri, onde está atualmente localizada a maior área de reflorestamento do Estado. Segundo Figueiredo ${ }^{10}$ et al. citado por Baena (1994), além de antecipar receitas para o dono da floresta, a resinagem "fixa o homem" no meio rural, porque é responsável por milhares de empregos diretos, gerando também muitos empregos indiretos por suas várias aplicações na indústria química.

Segundo a Associação dos Resineiros do Brasil, no Estado de São Paulo há aproximadamente 10.000 pessoas trabalhando na extração de goma resina. Caser, et al (1998) estima que $86,9 \%$ da resinagem no Estado de São Paulo está na Região Sudoeste do Estado, no polígono delimitado pelos municípios de Avaré, Itapetininga, Vale do Ribeira e Itararé, e emprega diretamente 6.000 pessoas.

O mesmo Autor comenta que o rendimento da operação de resinagem é de 120 árvores/homem/dia, o que resulta em 15.120 árvores/homem/safra ${ }^{11}$ para a ARESB, o rendimento é de 10.000 árvores/homem/safra, realizando todas as etapas, com retorno a cada 14 dias. No

\footnotetext{
${ }^{9}$ Divisão do Forest Service que se ocupa das gomas resinas dos Pinus

10 FIGUEIREDO FILHO, A.; MACHADO, S. do A.; HOSOKAWA, R. T.\& KIKUTE, P. Avaliação econômica da resinagem em florestas de Pinus elliottii Engelm. Var. elliottii. IPEF, Piracicaba, $n^{\circ} 45$, p.48-63, 1992.

${ }^{11}$ A safra da resinagem dura 9 meses.
} 
inicio da resinagem, em 1981, este número era de 5.000 árvores/homem/safra, para retorno a cada 14 dias, ou 7.000 árvores/homem/safra, para retorno a cada 21 dias, como narra Polesi (1983).

O mesmo Autor relata que era fundamental, para um bom rendimento, que o trabalhador morasse nas proximidades, "podendo ser ajudado por membros da família na execução de algumas tarefas, como aplicação de pastas ácidas ou mesmo a coleta da resina." (sic) (Polesi, 1983:37).

Em 1977, uma avaliação dos impactos do reflorestamento após 10 anos de incentivos fiscais, realizada pela Sociedade Brasileira de Silvicultura - SBS, já questionava a idéia de que um dos aspectos positivos do reflorestamento, no setor social, seria o de evitar o êxodo rural, e trazia uma cópia de uma reportagem publicada no Diário de São Paulo, de 24/3/72, que mostrava um jovem de 14 anos que trabalhava como espantalho vivo em um viveiro de mudas florestais. $O$ artigo continuava:

"... Como João, muitos outros jovens encontraram condições de trabalho, junto com seus pais e irmãos, melhorando o nivel de rendimento e, conseqüentemente, da vida, de toda a família. E seu pai, força da absorção de seu trabalho, mão-de-obra semiqualificada, abandonou a idéia de buscar nos grandes centros urbanos o trabalho necessário ao sustento dos seus, fixando-se à zona rural em que nasceu, casou-se e teve prole numerosa. Evitando o êxodo rural as florestas artificiais implantadas atualmente no Brasil possibilitam o alargamento das oportunidades de trabalho:..."(sic.) (Victor, 1977: 32)

O argumento da geração de emprego para justificar a atividade como social é bastante frágil, quando se leva em conta as condições de vida e moradia dos trabalhadores, no caso da resinagem e a concentração fundiária no caso do reflorestamento. 
Com o crescimento da industrialização, os usos da resina foram se ampliando de forma que hoje se conhece, de acordo com Augusto Filho (1994), pelo menos 30 usos para a colofônia tais como: tintas, vernizes, cola de papel, produção de plásticos, lubrificantes, adesivos e borracha sintética até chicletes e 40 usos para a terebintina: solventes de tintas especiais, matéria-prima para industria farmacêutica, perfumaria e produtos de limpeza (ver Figura 3, página 20).

A China é o maior produtor de goma resina do mundo. Segundo Stecca e Neves (1998) $)^{12}$, a China produz 700 mil toneladas/ano, enquanto a Indonésia e o Brasil disputam o segundo lugar no mercado com uma produção média de 65.000 toneladas, sendo que de acordo com Caser et al. (1998) o Estado de São Paulo apresenta o maior número de resinadores e florestas exploradas para esta finalidade. Entretanto esta produção já foi mais alta. Augusto Filho (1994), Baena (1994) e Rostelato (1996) relatam que, no período de 1994-1996, o Brasil exportava, principalmente para a Índia e Europa, sendo que o Estado de São Paulo detinha $70 \%$ de toda produção brasileira, cerca de 70.000 ton. anuais. Segundo Baena (1994), desse total, 45.000 ton. eram industrializadas internamente e 25.000 ton. eram exportadas in natura para Portugal, Índia e Argentina.

A China com aquela produção média, é dona de $60 \%$ do volume mundial, interfere nos preços da matéria prima e de seus derivados, afetando inclusive o mercado brasileiro (Augusto Filho, 1994).

Stecca \& Neves (1998), visitando áreas de exploração na China, relatam que a atividade é exercida por pequenos produtores, que se ocupam de pequenao número de árvores $(1.000$ a 1.500$)$ de propriedade do Estado, resinando-as intensivamente. Têm facilidade no escoamento da goma-resina, pois além de uma malha de canais maritimos que favorecem o transporte, as fábricas, ou alambiques, estão próximas às áreas de resinagem. Pelo fato de não pagarem arrendamento, nem incidir sobre a exploração, encargos trabalhistas e impostos

$124^{\circ}$. Encontro sobre goma resina, Itapeva, SP - Palestra "Explanação sobre o encontro Naval Store e visita à China", proferida por Roberto Groes Stecca e Augusto de Assis Neves. 
sobre o produto primário, no âmbito internacional o produto chinês é bastante competitivo.

Caser (1998) prevê uma elevação dos preços da resina praticados pela China, como resultado da política salarial e aumento do consumo interno, o que proporcionará novas perspectivas ao mercado brasileiro.

O valor médio da goma resina, que era de $U \$ 330 /$ ton. em 1994, caiu para $U \$ 240 /$ ton., em 1996, de acordo com a Fundação Florestal, a colofônia sofreu uma baixa de U\$700/ton. para U\$520/ton. (Augusto Filho, 1994) e segundo Caser (1998) o preço médio de venda da goma resina em 1998 era de U\$ 495/ton.

Os itens envolvidos na atividade de produção do breu, segundo Homa (1983), são:

- aluguel de árvores

- Produção de resina por árvore

- Custo financeiro da resinagem

- Despesas operacionais da resinagem

- Despesas de transporte

- Despesas de refinação

Os custos da exploração da goma-resina têm como variáveis: a estrutura da empresa; o potencial da floresta resinada, e suas peculiaridades, como intensidade de manejo, condições topográficas entre outras; qualidade da mão-deobra empregada, uma vez que a atividade de extração é totalmente artesanal; além do preço praticado no mercado. No início da atividade no Brasil, a industria fornecia todo o suporte para o empresário, que fazia a extração da goma resina na floresta, desde o material até o pagamento da mão-de-obra em troca da exclusividade de compra da produção.

Rostelato (1996) estima que os gastos com mão-de-obra representam $40 \%$ dos custos operacionais. Nicolielo (1983) quando listou os itens 
de custos de produção para regiões tropicais, encontrou um percentual maior: 75\% de custos com mão-de-obra distribuídos em 30\% para cortes (estrias), 16\% para a aplicação de pasta e $29 \%$ para a coleta; os restantes $25 \%$ ficariam por conta do custo da depreciação do material.

Os custos de mão-de-obra foram responsáveis pela redução da produção de resina em Portugal, que já chegou a produzir 120.000t/ano de resina, segundo Ferreira ${ }^{13}$, citado por Baena (1994). Em 1993, aprodução não ultrapassava 40.000t, pois com a unificação européia em 1993, o custo da mão-deobra aumentou, ameaçando inviabilizar a resinagem em Portugal, como já havia ocorrido na França, na década de 60.

Nos Estados Unidos, a área de resinagem abrangia 500 mil hectares da Região Sul, em 1946, conforme Gurgel Filho (1972), sendo que o Estado da Geórgia, empregava de 20 a 25 mil pessoas por ano na resinagem de aproximadamente 34 milhões de árvores de Pinus elliottii Engelm. var. elliottii e Pinus palustris Miller. Em 1970, o número de trabalhadores envolvidos na coleta de resina era de aproximadamente 3.500. Fato explicado pela quantidade de mão-deobra necessária à atividade e o seu encarecimento, o que levou à substituição da resinagem de árvores vivas pelo tall oil.

No início da década de 80 , quando estes custos foram levantados, o método de resinagem era diferente, as calhas eram pregadas nas árvores e os cadinhos de polietileno recebiam pregos de aço, com cabeça dupla, como suporte. Este método trouxe problemas com a industrialização das toras de árvores resinadas. Entre 1984 e 1988 passou-se a utilizar calhas batidas, cadinhos de polietileno e cavilhas de madeira.

A extração da resina, na década de 80 , utilizando-se estes métodos, consistia das seguintes fases, conforme Osório (1983):

\footnotetext{
${ }^{13}$ FERREIRA, A.P. A resinagem no Estado do Paraná. Irati: SESI,1993.
} 
Limpeza da casca: raspagem das árvores com remoção da casca, com rendimento de 400 faces/homem/dia;

Aplicação das calhas: que podia ser uma calha curva e cavilhas de madeira (sistema português), ou duas calhas em ângulo, fixados com pregos de cabeça dupla (sistema tradicional) fixadas no tronco, com rendimento de 800 faces/homem/dia para o sistema português e 350 faces/homem/dia para o sistema tradicional;

Marcação do painel: que servia de guia para as estrias evitando futuros vazamentos, com rendimento de 450 faces/homem/dia;

Colocação de cubas: que recolhia a resina que escorria do tronco, com rendimento de 1000 cubas por dia no sistema português e 200 cubas por dia no sistema tradicional;

Estriagem: a estria tinha a largura previamente marcada no painel, e periodicidade de 14 dias, com rendimento era de 1.600 faces/homem/dia.

Correção de vazamentos: os vazamentos eram corrigidos com aplicação de palhetas laterais, ou pequenas chapas que encaminhavam a resina para as chapas, com rendimento de 560 faces/homem/dia. 


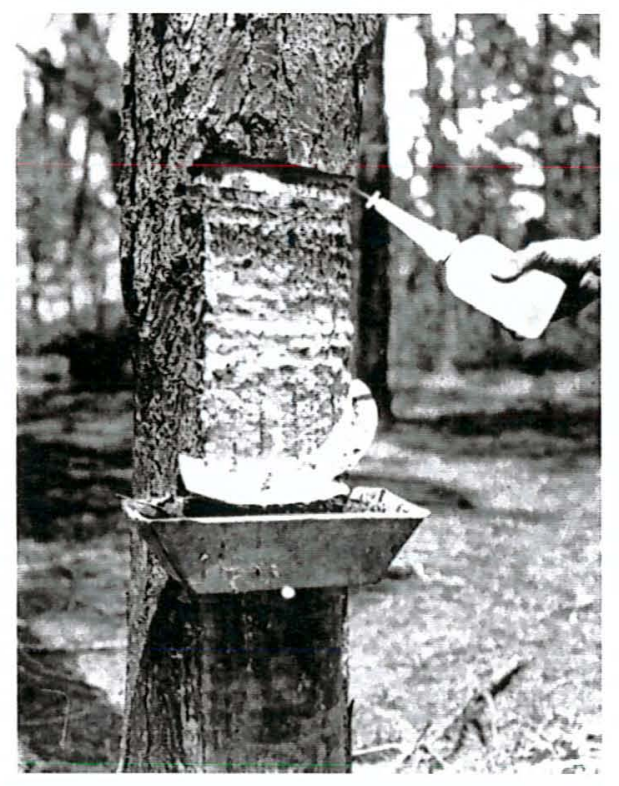

Figura 7: Resinagem utilizando o método das calhas pregadas

A partir de 1988, passou-se a utilizar sacos plásticos fixados com arames galvanizados e hastes, protegendo totalmente a madeira de elementos que pudessem causar danos às serras e lâminas, no processo produtivo, além de reduzir os custos de mão-de-obra. (Baena, 1994).

Polesi (1981) relata que o rendimento da raspagem da árvore era de 350 árvores/dia e a instalação do cadinho e das canaletas era na base de 120 operações/dia. O encarregado de uma das resinagens estudadas emitiu opinião diferente sobre o método das calhas e seus rendimentos, segundo ele: "o método do saquinho além de ser mais barato para o empresário, é mais prático e seguro para o trabalhador. Antes, para grampear a calha e colocar os contêiner ${ }^{14}$, o rendimento era de 200 faces/homem/dia, contra 300 faces/homem/dia para fazer o risco e amarrar os saquinhos. Além disto as calhas galvanizadas cortavam a mão do trabalhador, acarretando muitas faltas por este motivo, e quando se utilizavam calhas de embalagem "longa vida", grampeadas nas árvores, os grampeadores

\footnotetext{
${ }^{14}$ Recipiente para coletar a resina na árvore.
} 
enroscavam." Polesi (1981) mencionava rendimentos de 300kg/dia para uma equipe de 15 pessoas para a coleta.

Os rendimentos aparentemente muito discrepantes, na realidade são bem próximos, variando de acordo com a habilidade do indivíduo/equipes, e a evolução do sistema coletor uma vez que Osório (1983) trata da operação individualizada na colocação de calhas sob pressão, e os demais do conjunto das operações de instalação na colocação de calhas pregadas.

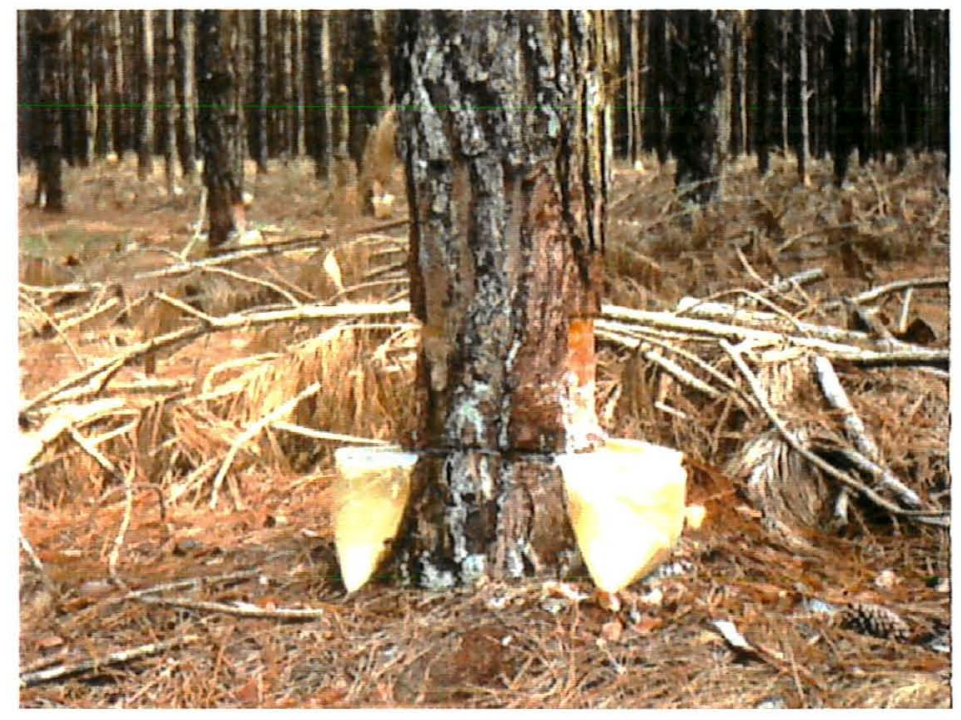

Figura 8: Resinagem pelo método do saquinho.

Os custos médios atuais da resinagem com insumos, utilizando-se o método do saquinho, são apresentados no Quadro 7. 
Quadro 7: Custos médios de insumos para a resinagem

\begin{tabular}{|c|c|c|}
\hline ITEM & UNIDADE & PRECO (US\$) \\
\hline Ácido sulfúrico $98 \%$ & ton. & 214.54 \\
\hline Almotolia & $\mathrm{dz}$ & 13.12 \\
\hline Arame $\mathrm{N}^{\circ} 22$ & $\mathrm{Kg}$ & 2,39 \\
\hline Balde (5I) & un. & .65 \\
\hline Bombona (50 1) & un. & 5.10 \\
\hline Bombinha $(201)$ & un. & 1.98 \\
\hline Estriador & ps. & 1.22 \\
\hline Farelo de arroz & ton. & 132.83 \\
\hline Lima K\&F & $d z$ & 43.03 \\
\hline Sacão $(100 \times 150 \times 0,20)$ & mil & 799.13 \\
\hline Saquinho & mil & 56.54 \\
\hline Tambor & un. & 56.54 \\
\hline Estria* & mil & 4.90 \\
\hline Coleta* & ton. & 22.26 \\
\hline Transporte - até $50 \mathrm{~km}$ & t. & 4.90 \\
\hline $51-150 \mathrm{~km}$ & t. & 10.42 \\
\hline $151-300 \mathrm{~km}$ & t. & 22.67 \\
\hline
\end{tabular}

Fonte: Florestar Estatístico, (1996). * Serviços

Ribas et al. (1984) estudaram os efeitos da resinagem no desenvolvimento das árvores e concluíram que há uma diminuição no incremento diamétrico de árvores resinadas, porém não há diferença significativa no incremento em altura entre árvores resinadas e não resinadas.

Figueiredo Filho, (1991), avaliando um povoamento de Pinus elliottii Engelm. var. elliottii, com 23 anos, localizado em Telemaco Borba, PR, concluiu que a floresta resinada apresentou um ganho de U\$ 504.30/ha em relação à floresta não resinada.

Lieberman \& Goolrick (1979) afirmam que apesar de os usos da goma resina terem mudado muito, desde a colonização americana, o mesmo não se pode dizer da industria da goma resina, que ainda é virtualmente sem mecanização e totalmente dependente da mão-de-obra. Uma das poucas inovações na resinagem deste século é o uso do ácido sulfúrico, que Fernandes et al. (1986) afirmam ter-se iniciado nos Estados Unidos em 1936. Segundo Berzaghi (1983) e 
Snow ${ }^{15}$ citado por Fernandes et al (1988) o ácido tem a função de aumentar e prolongar a exsudação, além de aumentar o intervalo entre os estriamentos.

As outras tranformações, no processo, foram:

a redução na concentração da pasta ácida de 50 - 60\% para aproximadamente $25 \% \mathrm{em}$ peso, com o acréscimo de farelo de arroz na composição, o que também permite um controle de aplicação, por formarem um filete negro quando aplicado;

substituição das calhas e cubas coletoras pregados, por sacos plásticos fixados por arames;

a largura da estria: de $5 \mathrm{~cm}$ para $2 \mathrm{~cm}$;

altura e largura do painel: hoje limitado à altura de $40-50 \mathrm{~cm}$ e largura de $14 \mathrm{~cm}$ a $18 \mathrm{~cm}$.

Essas mudanças proporcionaram um maior tempo de resinagem pois em uma árvore há a possibilidade de fazer de 4 a 5 painéis, bem como explorar faces concomitantemente.

Atualmente, o método do saquinho, é o mais utilizado na resinagem, segundo Garrido et al. (1998), consistindo das seguintes etapas:

$1^{a}$. - Escolha da árvore - as árvores a serem resinadas devem ter um diâmetro igual ou superior a $15 \mathrm{~cm}$;

$2^{\mathrm{a}}$. - Limpeza de tronco - utilizando-se o raspador de cascas, procurando deixar uma superficie lisa sem causar ferimentos ao lenho;

15 SNOW, A.G. The use of chemical stimulants to increase gum yields in slash and longleaf pinus. USFS Occasional Paper, 106, 1944, p.36 
$3^{\mathrm{a}}$. - Confeç̧ão do "bigode" - consiste em uma incisão na casca da árvore para a fixação do saco plástico coletor de resina;

$4^{a}$. - Colocação do recipiente coletor - os sacos plásticos são fixados por meio de arame, evitando que o escorrimento da resina ocorra entre o saco plástico e a casca da árvore;

5a. - Estriagem - o ferro estriador deve penetrar na árvore até a região do cambio vascular, expondo os canais resiníferos. Em geral a estria é feita de 2 a $3 \mathrm{~cm}$ de largura e o seu comprimento depende do diâmetro da árvore e do tamanho do saco coletor. São realizadas a cada 15 dias e se iniciam em meados de setembro, quando a temperatura começa a subir e vai até o final de maio.

$6^{a}$. - Estimulação química - aplicação da pasta acida com o auxílio de uma bisnaga.

Devem ser tomados alguns cuidados para evitar painéis espiralados, de forma que as estrias fiquem paralelas entre si, tendo o painel uma forma retangular. O painel espiralado provoca uma perda de resina pelo escoamento lateral ao saco plástico. Uma safra compreende de 18 - 19 estrias, ou seja um painel de aproximadamente $40 \mathrm{~cm}$ de altura.

Cada empresário faz a sua pasta acida, para distribuir em todas as áreas. A fabricação é mecanizada, e consta de uma mistura de farelo de arroz com água à qual é adicionada ácido sulfúrico. Ela é distribuída para todas as áreas.

A seqüência das operações segundo o encarregado de campo de uma empresa resineira, assim como os seus rendimentos são apresentados a seguir:

1a. Operação: alisamento da casca, no inicio da safra, geralmente efetuada por homens, por ser uma tarefa mais bruta, com o rendimento médio de 400 faces/homem/dia;

2a. Operação: colocação completa do saquinho, compreendendo o risco e a amarração, realizada indistintamente por homens, mulheres e menores 
com o rendimento médio de 300 faces/homem/dia. A amarração do saquinho é uma atividade que exige cuidados para evitar vazamentos. É feita uma vez à cada ano, na época de descanso da árvore e todos os trabalhadores participam;

3a. Operação: abertura da primeira estria, as primeiras duas estrias, exigem mais ácido para abrir os canais resiníferos e têm um rendimento de produção menor que as outras, por se localizar à $20 \mathrm{~cm}$ do solo exigindo que o trabalhador trabalhe sentado no chão ou ajoelhado; é mais realizada por homens, com o rendimento médio de 800 faces/homem/dia;

4a. Operação: estriagem e aplicação do ácido, atividade preferencialmente masculina. Ela é proibida para menores de 18 anos. O rendimento médio é de 1.500 faces/homem/dia, sendo o mínimo aceitável de 1.000 faces/homem/dia e o máximo de 3.000 faces/homem/dia. Ela rende ao trabalhador $\mathrm{R} \$ 7,50 /$ milheiro. As estrias do $5^{\circ}$. ano são mais difíceis, pois estão a $2,20 \mathrm{~m}$ de altura e tem a forma de $\mathrm{V}$, sendo portanto duas. Elas rendem ao trabalhador $R \$ 12,00 /$ milheiro, sendo o rendimento mínimo de 1.200 faces/homem/dia e o máximo de 1.800 faces/homem/dia.

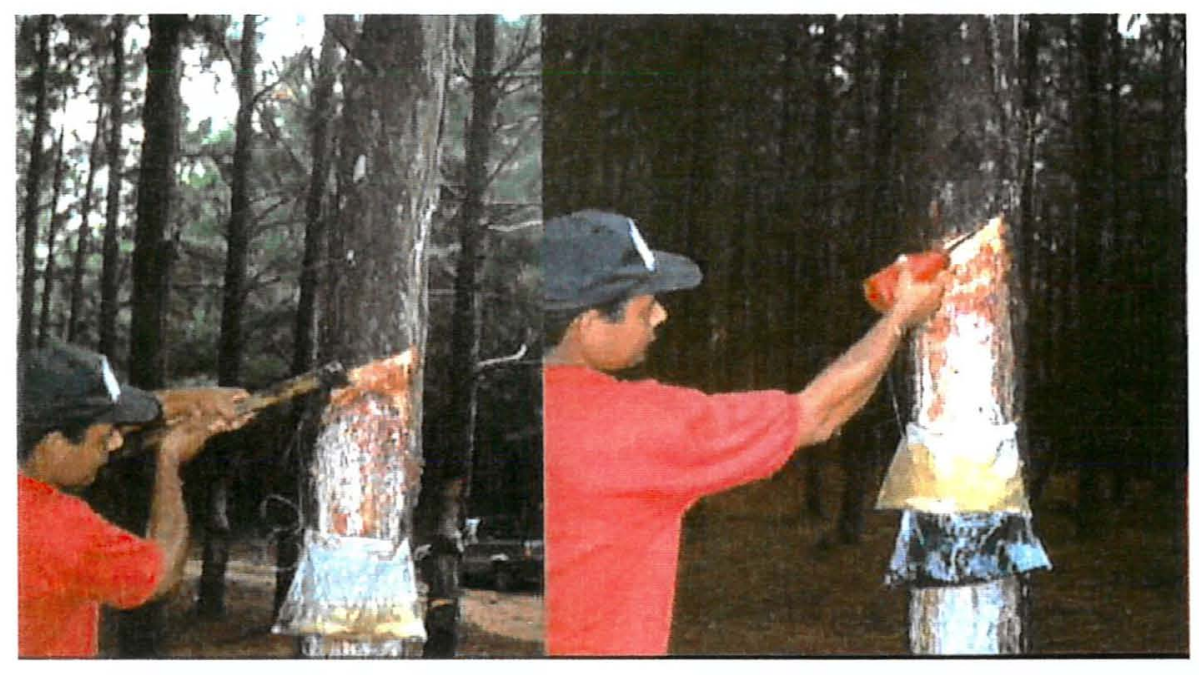

Figura 9: Operação de estriagem e aplicação da pasta ácida. 


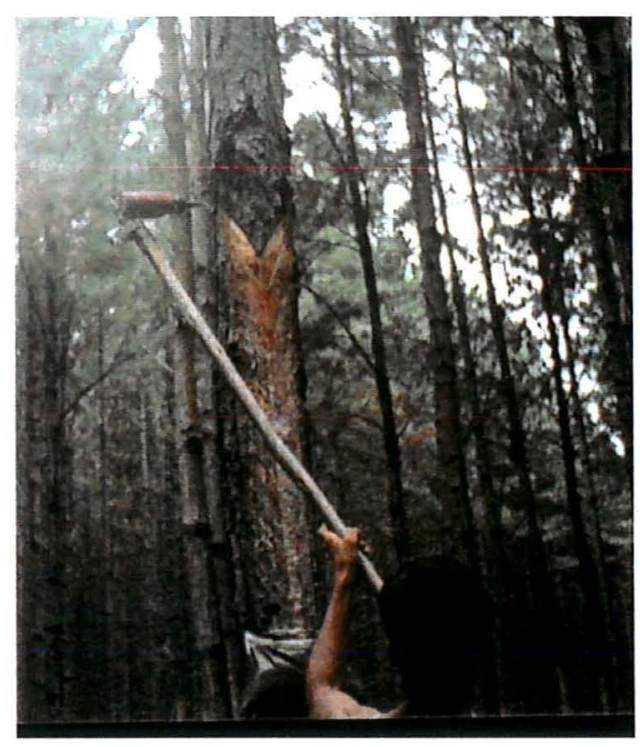

Figura 10: Feitura da estria em "V"

5a. Operação: coleta, atividade realizada de preferência por mulheres e menores. O rendimento médio é de 3 tambores ${ }^{16} /$ homem/dia. Ela depende também da distância entre as árvores do talhão e da produtividade da árvore, sendo o mínimo de 2 tambores/dia e o máximo de 4,5 tambores por dia.

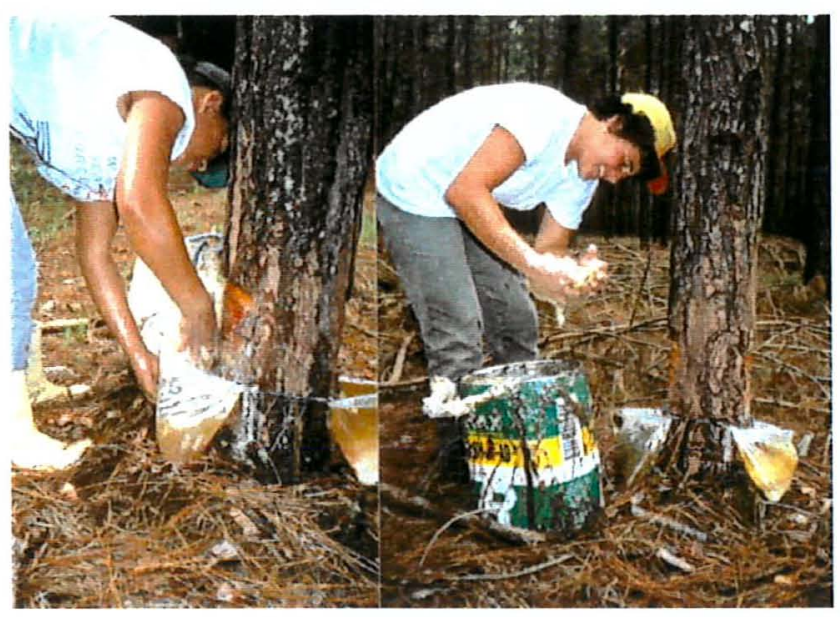

Figura 11: Operação de coleta da goma resina.

${ }^{16}$ capacidade do tambor - $190 \mathrm{~kg}$ 
6a. Operação de revisão: depois da passagem do coletor, há o pessoal que vem repondo os saquinhos danificados durante a coleta. Há, em média, uma perda de $20 \%$ dos saquinhos em cada safra. Os saquinhos trocados nesta etapa são colocados $2 \mathrm{~cm}$ abaixo da última estria realizada. Os trabalhadores nesta atividade são mulheres, menores e idosos e são diaristas.

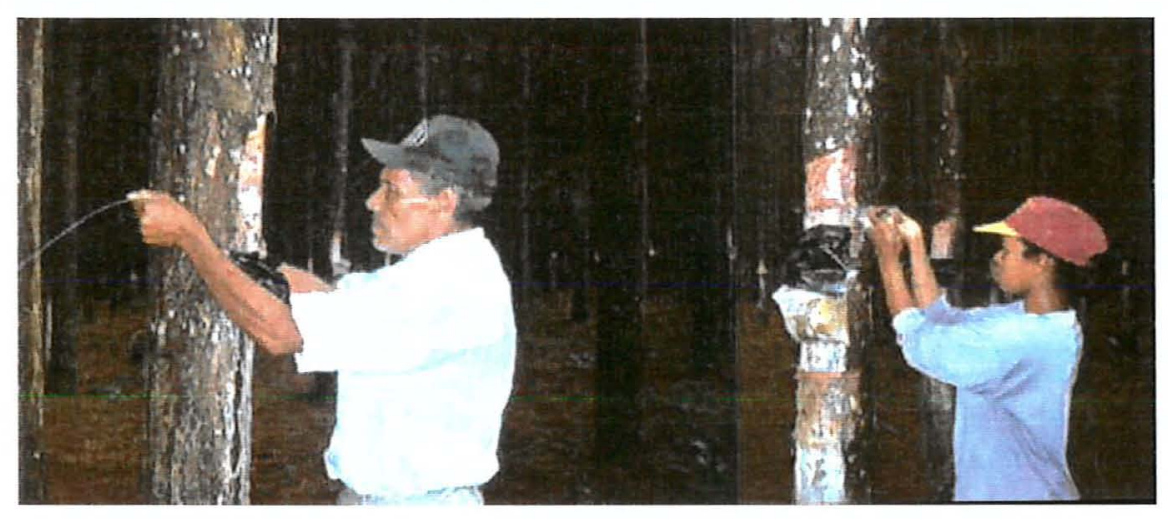

Figura 12: Operação de revisão.

7a. Operação: Fechar o tambor e limpeza da resina, tirar a água e a casca. Para tanto o trabalhador usa um pau com dois pregos. É tarefa masculina, ocupa dois diaristas homens.

8a. Operação: Transportar os tambores ao local de armazenamento. São necessários dois tratoristas. Tem salário mensal fixo.

9a. Operação: a última atividade, no final da safra, é a raspagem da goma que se solidifica no painel de resinagem. O rendimento médio é de 600 árvores/homem/dia a $\mathrm{R} \$ 20,00 /$ milheiro, sendo o rendimento mínimo de 400 árvores/homem/dia e o máximo de 800 árvores/homem/dia. O produto da raspa de painel é vendido para a industria, pela metade do preço da goma-resina.

A preparação dos saquinhos é "terceirizada", por exigir uma grande produção e ter baixo rendimento. Geralmente os saquinhos são preparados pelo pessoal que fica em casa, o próprio empregado da resinagem, à noite, e seus familiares: a mulher que não pode ir trabalhar para cuidar dos filhos e as crianças 
menores de idade que estão impedidas legalmente de trabalhar. $E$ paga $R \$$ $12,00 /$ milheiro.

Há ainda: um supervisor, que acompanha e fiscaliza estas atividades para toda a turma e um encarregado para cada 15 pessoas, sendo que no acampamento estudado são 3 para a estriagem, 1 para a coleta e 1 para a revisão. Estes recebem um salário fixo.

Quando o empregado é contratado, nos primeiros 3 dias, ele recebe treinamento, algumas etapas são mais simples de aprender, enquanto outras, como a estriagem, exigem uma habilidade que nem todos possuem. Durante este período o empregado é avaliado em suas aptidões e encaminhado ao processo em que melhor se adapte. Neste período ele recebe diárias.

Há que se observar que existe uma certa "especialização" na atividade. Porém, o empregado quando indagado sobre a sua profissão durante a entrevista não menciona esta especialização, por exemplo: estriador, coletor ou revisor. A grande maioria se qualifica como trabalhador braçal, pois alegam que apesar de, na maior parte do tempo, serem apenas estriadores, ou coletores, etc., em algumas épocas do ano, como: nas instalações de novas áreas de resinagem, na época de descanso das árvores, etc. fazem capinas, ou instalações, ou revisões, etc.

Acompanhamos durante uma semana as operações de estriagem normal e em $V$, cronometrando os tempos gastos. Verificamos que um estriador é capaz de fazer uma média de 3,5 a 6 estrias normais por minuto, com algumas paradas para tomar água, recarregar a bisnaga de ácido e afiar o estriador. No entanto a estria em $V$ é mais demorada e apresenta uma média de 3,6 estrias/minuto.

Está em experimentação um novo método de resinagem, denominado: "sistema fechado de extração de resina", que utiliza uma garrafa plástica , tipo PET de 2 litros, que é introduzida em um orifício na base da árvore, para coletar a resina. Este método apresenta, segundo Garrido et al. (1998), as 
seguintes vantagens: pequena agressão à madeira, redução da evaporação da terebintina e diminuição do teor de impurezas. Assim obtem-se uma resina de melhor qualidade. Os empresários da resina também comentam que este método diminuiria a mão-de-obra necessária à extração. Aoki e Cruz (1998) acrescentam que este método traz ainda benefícios ao meio ambiente uma vez que oferece utilização para as garrafas descartáveis.

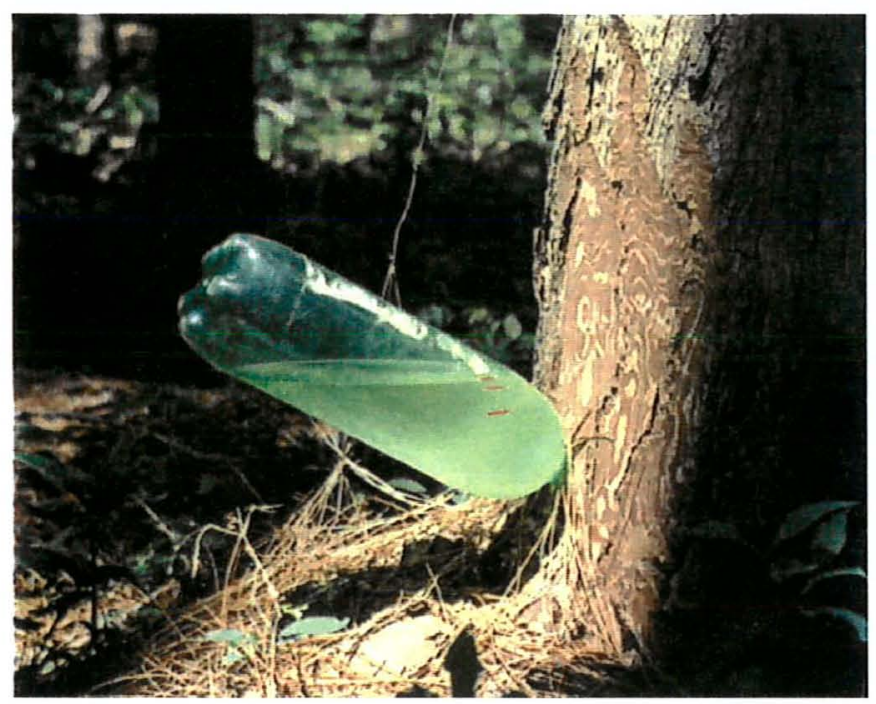

Figura 13: Sistema fechado de resinagem

Os rendimentos do sistema fechado de resinagem encontrados por Aoki \& Cruz (1998), foram melhores no segundo ano, depois de um ajuste na metodologia utilizada, sendo que quando se utilizaram duas garrafas/árvore atingiu-se uma média de $1.110 \mathrm{~g} / a ́ r v o r e$.

Hodges \& Williams (1993) conseguiram um rendimento por furo, em Pinus elliottii, de $708 \mathrm{~g}$, sendo que quando utilizaram 3 garrafas a produção por árvore foi de 2,04kg, para a mesma espécie. Os autores ponderam que observações sugerem que é possível a produção continuada de uma dada árvore, colocando-se garrafas nos mesmos furos, ou perfurando-se novos orifícios, próximos aos antigos e instalando-se novas garrafas. 
Hodges (1998), utilizando sistema fechado, porém com buracos de 3,8 a $5,0 \mathrm{~cm}$ de diâmetro, atingiu um rendimento médio de resina por perfuração e por árvore de 676g/árvore. O autor afirma que o rendimento de Pinus elliottii melhorado, é significantemente maior que o de árvores não melhoradas em sítios próximos. Afirma também que orifícios de 3,8 a $5,0 \mathrm{~cm}$ de diâmetro em duas ou três perfurações produzem rendimento de $92 \%$ superior ao orifício padrão de 2,5 $\mathrm{cm}$, com um único buraco. O Autor conseguiu um rendimento em Pinus elliottii melhorado de $1.837 \mathrm{~g}$ /árvore, utilizando 2 ou 3 perfurações. O Autor cita que o custo do processo por árvore é de $U \$ 1.08$, ou $U \$ 0.36$ por perfuração.

Pelos métodos tradicionais a média histórica de produção anual por árvore é de $2.500 \mathrm{~g}$, sendo que o melhoramento genético pode proporcionar aumentos superiores a 100\% na produtividade, com árvores produzindo 5.000 $7000 \mathrm{~g}$ por ano. Na Estação Experimental de Itapetininga, existe uma árvore produzindo $11.000 \mathrm{~g} / \mathrm{ano}$, podendo ser, por isto, selecionada para fins de melhoramento genético, pois segundo Romanelli (1988) a característica da produção de resina é altamente favorável para programa de melhoramento genético, pois permite a obtenção de ganhos de seleção estimados em 100-110\% através de pomares clonais.

No Brasil, atualmente, os trabalhos de pesquisa em relação a goma resina, se concentraram na produtividade da floresta: a qualidade e utilização da resina, manejo florestal, melhoramento genético, efeitos da resinagem na qualidade da madeira, efeito de solo e clima, economia, processamento e composição química da resina. Conforme levantamento dos trabalhos de pesquisa sobre resinagem realizados no Estado de São Paulo, apresentado por Aoki (1998) no $4^{\circ}$. Encontro sobre Goma-resina, não há estudos que relacionem a interferência da mão-de-obra no processo, (Anexo 2).

A utilização de garrafas ainda não é uma prática comum, ela tem a intenção de diminuir a quantidade da mão-de-obra. Mas esta técnica até agora é recomendada às espécies de resina, mais liquidas, com alto teor de terebintina. 
Augusto Filho (1994) relata que a redução do valor da resina, causada pela concorrência feita pela China, fez com que algumas empresas se afastassem do segmento e que parte da mão-de-obra atuante procurasse outras ocupações, fazendo com que aquelas que permaneceram no segmento começassem a se preocupar com mão-de-obra utilizada na coleta.

O mesmo Autor afirma que na sua empresa os trabalhadores na resinagem recebem um treinamento: Formação Profissional Acelerada - FPA, que com vários exercícios práticos visa qualificar o resinador. Outra iniciativa de se treinar mão-de-obra foi realizada pelo SENAR - Serviço Nacional de Formação Profissional Rural, ligado na época ao Ministério da Agricultura, com a Coleção Básica Rural, que no volume Silvicultor tem um capitulo sobre resinagem, onde ensina desde como montar as ferramentas para resinagem até a instalação dos painéis.

Dentre as atividades de exploração florestal a resina é a maior geradora de empregos, uma vez que é de difícil mecanização. Garrido et al. (1998), calculam que, no Brasil, na exploração de mais de 45 milhões de árvores, são gerados mais de 10.000 empregos diretos.

Estudando os madeireiros do Sul dos Estados Unidos, Bliss \& Flick (1994) afirmaram que a industria da resina ("naval stores") e da madeira requerem milhares de trabalhadores dispostos a realizar um "trabalho físico, pesado, quente $e$ tedioso por uma compensação mínima" (Bliss \& Flick, 1994: 79) e rematam alegando que ambas as industrias inicialmente utilizavam trabalho escravo.

Segundo Baena (1994) quando não se faz aplicação de pasta ácida o maior volume exsudado ocorre no primeiro dia após o corte da estria, declinando até o quinto ou sétimo dia. Quando se aplica a pasta ácida a exsudação é abundante até $07^{\circ}$. dia, quando começa a diminuir até o $14^{\circ}$. dia. No Brasil as estria são feitas a cada 15 dias. Fica clara a influencia da mão-de-obra no processo de extração, praticamente determinando o intervalo de tempo entre as estrias, sendo que nos países onde o custo de mão-de-obra é elevado, como os Estados 
Unidos, a extração a partir de árvores vivas é pequena, sendo utilizado preferencialmente o tall oil.

\section{A resinagem em áreas do Instituto Florestal}

O Instituto Florestal - IF, foi um dos pioneiros em oferecer suas florestas para exploração de resina por terceiros. Ao longo dos tempos as suas normas de comercialização foram sendo aperfeiçoados e serviram de modelo para os arrendamentos em áreas particulares.

Na década de 70, os contratos de compra e venda eram firmados em regime de "matagem", onde o comprador arcava com as despesas necessárias à atividade e a resinar dentro das normas técnicas, tendo como base o "Manual da Moderna Resinagem" (Clements, 1970).

As árvores destinadas a resinagem, geralmente aquelas à serem cortadas no próximo desbaste, eram selecionadas e marcadas pelo Instituto Florestal.

O contrato tinha duração de 36 meses, a partir da assinatura, sendo que o período anual de produção da resina seria de 9 meses, compreendendo a época mais propicia à pratica da resinagem, nos meses de setembro a maio. Nos restantes o If faria a derrama e os desbastes. Os carregamentos do produto saia do local acompanhado da Nota Fiscal de Produtor, com alusão ao contrato.

O empresário era responsável pelos encargos trabalhistas, previdenciários, fiscais e comerciais, para explorar e retirar a resina do local.

O preço de venda, por quilo, da goma-resina e da raspa era estipulado na tabela de preços de sementes, mudas, produtos e subprodutos florestais, fixado por meio de Portaria da Coordenadoria da Pesquisa de Recursos Naturais - CPRN. O pagamento era feito em cheque visado a favor do Fundo Especial de Despesa do Instituto Florestal, pagável na praça de São Paulo. 
Por efeito de contrato, o comprador tinha que fornecer ao IF os dados relacionados com a extração, produção e custo da resina, em todas as suas fases.

O empresário podia instalar um acampamento, em local designado pela Chefia da Floresta Estadual ou Estação Experimental, em que se realizava a resinagem, às suas expensas, de caráter provisório, para ser demolido impreterivelmente 30 (trinta) dias após o término contratual, e sem direito a indenização, qualquer que fosse. Era também responsável por todos os atos de seus empregados, com respeito à segurança, a moral e disciplina no local. A Chefia, podia solicitar a retirada do serviço dos empregados da resinagem que não respeitassem as normas em vigor no lugar.

Essa cláusula que permitia a construção de moradias desde que fossem provisórias, nos casos dos acampamentos dentro de áreas estaduais, visava proteger o patrimônio do Estado de futuras reivindicações dos empresários, no caso de fazerem investimentos nas áreas de domínio público. Essa cláusula visa atender ao que dispõe o Artigo. 547 do Código Civil:

"Aquele que semeia, planta ou edifica em terreno alheio perde, em proveito do proprietário, as sementes, plantas e construções, mas tem direito à indenização. Não o terá, porém, se procedeu de má-fé, em que poderá ser constrangido a repor as coisas no estado anterior e pagar os prejuizos."

No caso de ocorrência de incêndio nas áreas em resinagem, por negligencia, ou culpa do comprador, ele tinha que ressarcir os prejuízos causados ao Estado.

Em meados da década de 80 , a venda de resina em regime de matagem, era objeto de Concorrência Pública, havendo um prazo de 5 dias consecutivos, a partir da data de publicação do contrato no Diário Oficial, para a instalação dos equipamentos necessários à resinagem. 
Havia uma quantidade total pré-fixada de resina, que deveria ser extraída e uma quantia mínima a ser retirada por árvore. Não se podia utilizar pregos metálicos na instalação e era estipulada a largura e o número máximos permitidos das estrias. Era estipulada uma multa por árvore danificada ou resinada indevidamente.

Também era punida com multa a perda da goma-resina, por falta ou má colocação dos recipientes, fixação inadequada ou não realização da coleta. 0 que ocorria quando os preços do produto estavam baixos no mercado.

A empresa compradora da resina passava a se comprometer, por força de contrato, a colocar a disposição do Instituto Florestal, uma pessoa treinada e capaz de fornecer dados para fins técnicos ou científicos, sendo este indivíduo escolhido de comum acordo entre as partes.

Os acampamentos eram permitidos nas mesmas condições da década anterior, tendo sido acrescentada a advertência de que 0 empresário era responsável pela indenização por danos que pudessem ocorrer, em decorrência dos mesmos.

Na década de 90 , a comercialização dos produtos florestais do IF já era responsabilidade da Fundação para a Conservação e a Produção Florestal do Estado de São Paulo - Fundação Florestal, que optou por realizar leilões das áreas de resinagem. Nestes, os interessados ofertam uma quantidade de resina por árvore, a ser entregue a Fundação Florestal. A entrega da resina é estipulada através de quotas durante a safra, sendo posteriormente leiloada.

Os acampamentos eram permitidos desde que satisfizessem as Normas e exigências dos órgãos oficiais, sendo vistoriados pela saúde pública. Em meados da década os contratos passaram a proibir a instalação de novos acampamentos.

Em janeiro de 2.000 o Instituto Florestal tem 1.200.151 faces em resinagem nas suas áreas na Mesorregião: Estação Experimental de Itapetininga, 
Estação Experimental de Buri, Floresta de Angatuba, Estação Experimental de Itapeva e Estação Experimental de Itararé.

\section{Características do trabalhador da resinagem}

Pela metodologia adotada, foi entrevistada uma pessoa em cada casa do acampamento. A grande maioria das respostas foi dada pelo trabalhador da resinagem. Em 28,57\% das casas do acampamento, as respostas foram dadas pelas mulheres. Nas outras situações notou-se uma timidez muito grande por parte das mulheres e das crianças, que se mantinham normalmente à parte, só falando quando diretamente indagadas.

A maioria dos trabalhadores da resina é casado ou amasiado $(75,61 \%)$. Este fato também foi observado por Noronha (1987),que encontrou entre os seringueiros do Acre uma taxa de $81 \%$ de casados ou amasiados. No caso da resinagem.

Quanto ao número de filhos: $41,17 \%$ dos moradores de acampamento, com idades entre 18 e 35 anos, têm de 1 a 3 filhos; 66,67\% dos moradores do bairro, com idades entre 18 e 35 anos, têm até 1 filho e na colônia estudada $47,62 \%$ dos moradores, distribuidos por todas as faixas etárias, não têm filhos.

A escolaridade também mostra uma diferenciação entre os casos estudados: os moradores do acampamento mostram um índice de analfabetismo maior $(42,86 \%)$ e os que mostram algum nivel de escolaridade não concluíram o primeiro grau, sendo que a maioria cursou apenas até a terceira série do primeiro grau $(37,14 \%)$. Já os moradores do bairro e da colônia apresentam um número menor de analfabetos: $19,05 \%$ dos moradores de colônia e 3,85\% no caso dos moradores do bairro, sendo que entre os últimos foram encontrados alguns casos de pessoas que iniciaram o segundo grau $(3,85 \%)$.

Quando comparamos estes resultados relativos à educação formal com os índices que o IBGE encontrou na Mesorregião de Itapetininga temos que 
$66,36 \%$ da população tem de 1 a 7 anos de estudo e $14,74 \%$ são analfabetos, verificamos que os moradores do bairro estão na média em relação ao tempo de estudo e em relação ao analfabetismo apresentam um índice menor que a média. Os moradores da colônia estão próximos à média regional em relação ao analfabetismo e tempo de estudo, enquanto os moradores do acampamento estão abaixo da média regional em relação ao tempo de estudo e apresentam um índice maior de analfabetismo.

De acordo com Gnaccarini (1993), a analise das informações estatísticas da Pesquisa Nacional por Amostragem de Domicílios de 1973, feita por Pastore, classifica os trabalhadores braçais da zona rural, pescadores e seringueiros, como ocupações relacionadas a índices ínfimos de escolarização no Brasil, afirmando ainda que "as pessoas que se encontravam nessas ocupações, no conjunto do País, detinham as seguintes taxas de escolarização: primário completo: 16\%; primário incompleto: 47\%; sem escolarização: 32\%" (Pastore, 1979, p. 97).

Noronha et al. (1987) considerou alta uma freqüência de $58 \%$ de alfabetizados, encontrada em 1982, entre os seringueiros do Acre que sabem ler e escrever, por considerar que o fato do seringueiro residir na mata, torna as oportunidades de aprendizado escolar escassas. O mesmo deve-se levar em conta no caso dos moradores do acampamentos de resinagem, já que nem sempre há escola próxima ao acampamento, ou facilidade para se deslocar até uma escola. Garcia (1994) relata que no acampamento abordado por ele, as crianças não freqüentavam a escola porque "... elas teriam que ir até a estrada esperar o ônibus da Prefeitura. É muito perigoso. Os adultos estão no campo e não podem acompanhar as crianças...".

No acampamento estudado, há uma escola municipal distante aproximadamente $800 \mathrm{~m}$, que oferece classes de pré escola até a $3^{\mathrm{a}}$. série do $1^{\circ}$. Grau. Há um ônibus da Prefeitura, que do mesmo local, transporta os escolares de $4^{a}$. série em diante, até a escola mais próxima. As crianças do acampamento sempre foram a minoria, em torno de $21 \%$, com uma taxa de freqüência baixissima, chegando em alguns casos a faltar durante semanas seguidas, segundo 
as professoras. Quando voltamos, no inicio de 1999 , para complementar algumas informações no acampamento, verificamos uma freqüência à escola de $94,73 \%$ das crianças com idade entre 7 e 14 anos.

Este fato nos levou a procurar as professoras da escola local, para sabermos o motivo desta mudança. Elas relataram que no inicio do ano, foram de casa em casa no acampamento, matriculando todas as crianças nesta faixa etária e informando aos pais, sobre a obrigatoriedade da freqüência e as penalidades a que estariam sujeitos caso não mandassem seus filhos à escola.

No bairro o índice de freqüência à escola nesta faixa etária é de $36,84 \%$ e na colônia estudada é de $31,25 \%$.

Outra caracteristica do trabalhador da resinagem, que mora no acampamento estudado é a sua permanência no mesmo emprego. Ele é o que apresenta menor taxa de permanência no local: $46,34 \%$ trabalham na resinagem há 10 anos ou mais, porém 70,73\% mora no acampamento deste empresário há menos de 3 anos, sendo que 19,51\% mora no local há menos de 1 ano, como se pode observar na Tabela 8.

Tabela 8: Relação entre tempo de trabalho e tempo de moradia no acampamento estudado

\begin{tabular}{|c|c|c|c|c|c|c|c|c|c|}
\hline \multirow{8}{*}{ 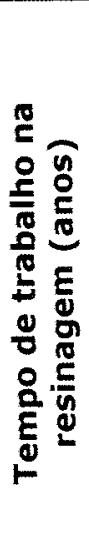 } & \multicolumn{9}{|c|}{ Tempo de moradia neste acampamento (anos) } \\
\hline & & $<1$ & $1-3$ & $3-5$ & $5-7$ & $7-9$ & $9-10$ & $>10$ & Lotal \\
\hline & $1-3$ & 0 & $\begin{array}{c}6 \\
100 \%\end{array}$ & --- & $-\cdot-$ & $-\cdot-$ & $-\cdots$ & --- & 6 \\
\hline & $3-5$ & 0 & $\begin{array}{c}1 \\
(25 \%)\end{array}$ & $\begin{array}{c}3 \\
(75 \%)\end{array}$ & $\cdots$ & $\cdots$ & $\cdots$ & $\cdots$ & 4 \\
\hline & $5-7$ & $\begin{array}{c}2 \\
(50 \%)\end{array}$ & $\begin{array}{c}2 \\
(50 \%)\end{array}$ & 0 & 0 & -- & --- & $\cdots$ & 4 \\
\hline & $7-9$ & $\begin{array}{c}2 \\
(40 \%) \\
\end{array}$ & $\begin{array}{c}2 \\
(40 \%)\end{array}$ & $\begin{array}{c}1 \\
(20 \%) \\
\end{array}$ & 0 & 0 & --. & $\cdots$ & 5 \\
\hline & $9-10$ & $\begin{array}{c}2 \\
(40 \%)\end{array}$ & $\begin{array}{c}2 \\
(40 \%)\end{array}$ & $\begin{array}{c}1 \\
(20 \%) \\
\end{array}$ & 0 & 0 & 0 & $\cdots$ & 5 \\
\hline & $>10$ & $\begin{array}{c}3 \\
(19 \%)\end{array}$ & $\begin{array}{c}6 \\
(38 \%)\end{array}$ & $\begin{array}{c}4 \\
(25 \%)\end{array}$ & $\begin{array}{c}2 \\
(12 \%)\end{array}$ & $\begin{array}{c}1 \\
(6 \%)\end{array}$ & 0 & $\mathbf{0}$ & 16 \\
\hline
\end{tabular}

Pode-se observar na Tabela 8 uma tendência de quanto maior o tempo de trabalho na resinagem, menor permanência no local, e isso tem sido observado em nossa vivência na vizinhança de um acampamento. Fagundes, 1992, 
discute a migração da mão-de-obra entre empresas extratoras, enfatizando a importância de cada empresa oferecer um treinamento aos seus empregados, objetivando que dentro deste rodízio, a cada nova contratação o trabalhador esteja mais qualificado.

Entre os entrevistados no bairro $84,62 \%$ trabalham na resinagem há menos de 8 anos e $84,62 \%$ moram no local há mais de 5 anos, como se observa na Tabela 9.

Tabela 9: Relação entre tempo de trabalho e tempo de moradia no bairro estudado

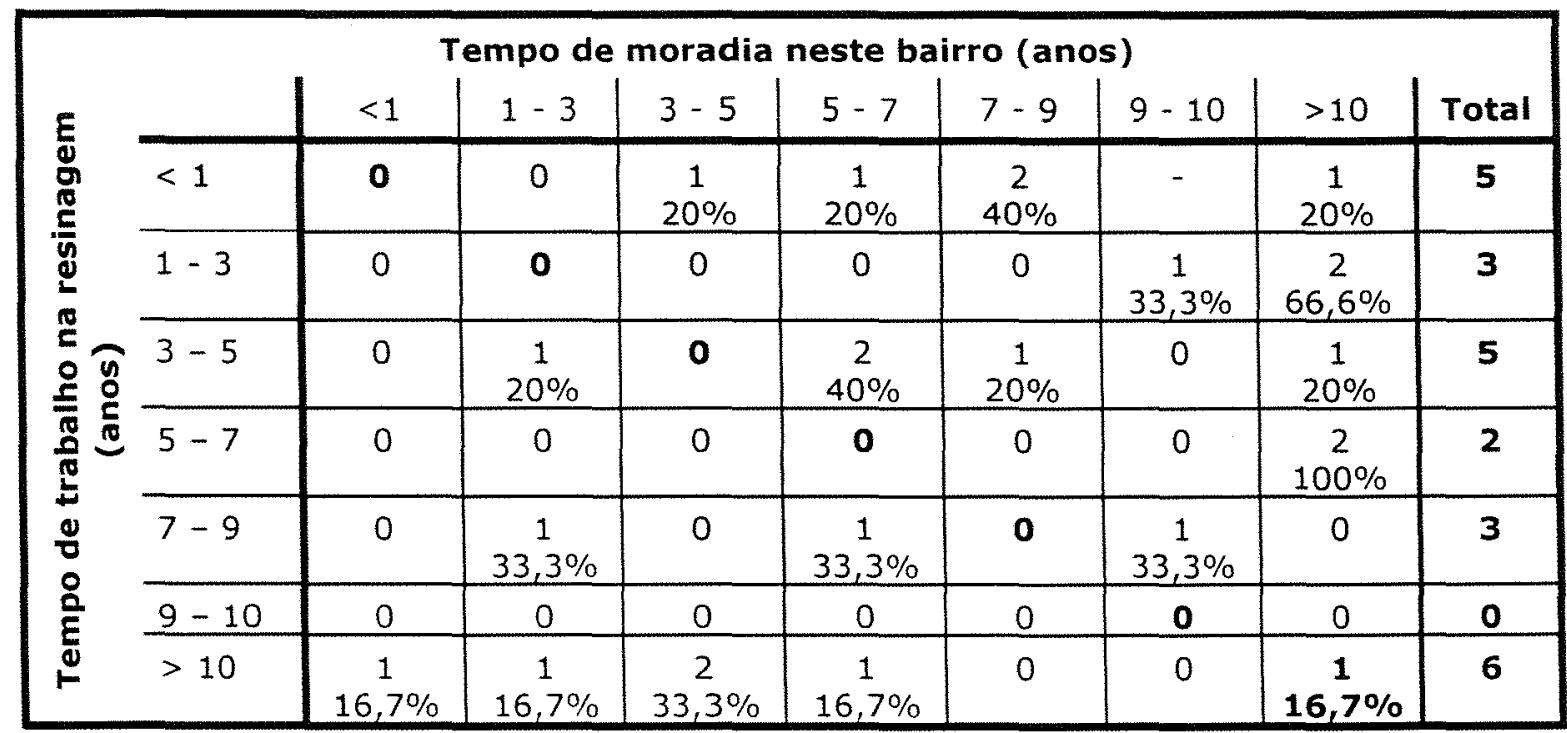

Pode-se observar que não há relação entre tempo de trabalho na resinagem e tempo morando no bairro, o que era esperado uma vez que são moradores do bairro, trabalhadores rurais, que foram contratados para trabalhar na resinagem durante o período deste contrato.

No caso da colônia estudada, ocorre uma situação intermediária entre - que acontece no acampamento e no bairro, uma vez que $76,19 \%$ trabalham na resinagem há mais de 7 anos e 38,10\% moram no local há mais de 5 anos, como pode ser visto na Tabela 10. 
Tabela 10: Relação entre o tempo de trabalho na resina e o tempo morando na colônia estudada

\begin{tabular}{|c|c|c|c|c|c|c|c|c|c|}
\hline \multirow{8}{*}{ 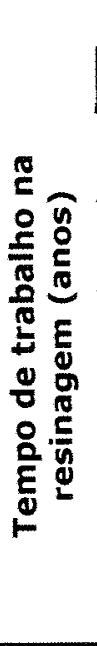 } & \multicolumn{9}{|c|}{ Tempo de moradia nesta colônia (anos) } \\
\hline & & $<1$ & $1-3$ & $3-5$ & $5-7$ & $7-9$ & $9-10$ & $>10$ & Total \\
\hline & $1-3$ & 0 & $\begin{array}{c}5 \\
100 \% \\
\end{array}$ & -- & - & -- & -- & -- & 5 \\
\hline & $3-5$ & 0 & $100 \%$ & 0 & -- & -- & - & -- & 1 \\
\hline & $5-7$ & $\begin{array}{c}3 \\
42,86 \% \\
\end{array}$ & 0 & 0 & 0 & $\begin{array}{c}4 \\
57,14 \% \\
\end{array}$ & -- & -- & 7 \\
\hline & $7-9$ & 0 & 0 & $\begin{array}{c}1 \\
33,3 \% \\
\end{array}$ & 0 & $\begin{array}{c}2 \\
66,6 \% \\
\end{array}$ & - & -- & 3 \\
\hline & $9-10$ & 0 & 0 & $\begin{array}{c}2 \\
50 \% \\
\end{array}$ & 0 & 0 & $\begin{array}{c}2 \\
50 \% \\
\end{array}$ & - & 4 \\
\hline & $>10$ & 0 & 0 & $\begin{array}{c}1 \\
25 \% \\
\end{array}$ & $\begin{array}{c}1 \\
25 \%\end{array}$ & 0 & 0 & $\begin{array}{c}2 \\
50 \%\end{array}$ & 4 \\
\hline
\end{tabular}

Os moradores da colônia estudada tendem a permanecer por maior tempo no local. Isto se deve principalmente ao fato de, neste caso, a resinagem se realizar em áreas próprias, o que oferece ao empregado a segurança em relação ao trabalho, aliado as condições oferecidas pela moradia

Os moradores do acampamento $(74,29 \%)$ e os da colônia $(61,90 \%)$ se declaram trabalhadores braçais e não resineiros, enquanto os moradores do bairro se declaram resineiros $(88,46 \%)$. Essa observação dos moradores do acampamento e da colônia se deve ao fato já mencionado: em certas épocas do ano esses trabalhadores fazem também capinas, limpeza de terreno, e outras atividades características do trabalhador braçal, e que são necessárias da mesma forma na resinagem.

O número de trabalhadores na resina por casa no acampamento é de 1 ou 2 (82,86\%); no bairro essa situação se repete em 92,31\% das casas, enquanto na maior parte das casas da colônia apenas uma pessoa trabalha na resina $(61,54 \%)$. Nas três situações todos têm carteira assinada, sendo a maior 
parte contratada como tarefeiro rural $^{17}$, exceto o encarregado, o supervisor, os tratoristas e o ajudante geral que recebem salário fixo.

No acampamento estudado, em todas as familias ${ }^{18}$ sem filhos, duas pessoas trabalham na resinagem; onde existe um filho, em 83,33\% dos casos, apenas uma pessoa trabalha na resina; nos casos em que aparecem um número maior de filhos, o número de pessoas que vai trabalhar na resina vai depender da idade do filho mais velho, se ele tem condições de cuidar do irmão menor, ou de trabalhar.

No bairro estudado, esta tendência muda: em $44,4 \%$ das famílias sem filhos, os dois trabalham na resinagem; em 33,33\% das residências entrevistadas, duas ou no máximo três pessoas trabalham na resina, independentemente do número de filhos.

$\mathrm{Na}$ colônia, em $83,33 \%$ dos casais sem filhos, apenas uma pessoa trabalha na resina; em $75 \%$ das familias com um filho, apenas uma pessoa trabalha na resina, e nos 25\% restantes, o filho é maior de idade e também trabalha na resina; em todos os casais com 2 ou 3 filhos apenas uma pessoa trabalha na resina, sendo que os filhos são pequenos; em $75 \%$ das famílias com 4 filhos ou mais, 3 ou 4 pessoas trabalham na resina, sendo que em $25 \%$ das casas restantes, apenas 1 pessoa é trabalhadora da resina.

Até alguns anos atrás era comum os filhos acompanharem os pais na resinagem. Atualmente, a fiscalização impede este tipo de procedimento, porém houve uma mãe, trabalhadora da resina, que contou que o filho de doze anos está trabalhando na colheita de feijão depois da escola, o que leva a supor que o

\footnotetext{
${ }^{17}$ tarefeiro rural - forma de contrato da CLT, onde o trabalhador recebe por produção mensal e nos casos em que a produção não atinge o salário minimo rural regional, que a partir de $01 / 10 / 98$ é de $R \$ 169,00$, o empresário é obrigado a fazer a complementação e 0 pagamento dos encargos sociais.

${ }^{18}$ No caso considerou-se apenas o núcleo familiar, ou seja os familiares residentes na mesma casas, não tendo sido levado em conta os laços familiares, entre moradores de residências diferentes.
} 
trabalho infantil continua em atividades agrícolas, onde a fiscalização é menos intensa.

Pode-se supor que como a pergunta é especifica: "Número de pessoas, da casa, que trabalham na resina?...", e tanto o acampamento, como a colônia estudados, se localizavam relativamente distantes da cidade, as chances de trabalho em outra atividade que não a resina, eram menores. O que não ocorre, no caso do bairro, em que outras oportunidades de emprego estão disponíveis, havendo oportunidades de trabalho em sítios, no comércio local, como empregada doméstica, etc.

Observa-se com relação ao salário que no acampamento estudado $37,14 \%$ dos tarefeiros recebem salários entre $R \$ 112,00^{19}$ e $R \$ 200,00 ; 45,71 \%$ entre $R \$ 200,00$ e $R \$ 300,00$, sendo que os encarregados de turma recebem um salário fixo de $R \$ 400,00$ - R\$500,00 e o supervisor também tem salário fixo de R\$ 600,00-R\$ 700,00. Na Colônia estudada $85,71 \%$ dos tarefeiros têm rendimentos entre $R \$ 112,00$ e $R \$ 200,00$, sendo que ajudante geral recebe salário fixo de $R \$ 112,00$ - $R \$ 200,00$ e o administrador recebe salário fixo de $R \$ 600,00$ - R\$700,00. No caso do bairro em questão, $65,38 \%$ dos tarefeiros têm rendimentos entre $R \$ 200,00-R \$ 300,00$.

No acampamento estudado, no mês de maio de 1999, os salários médios por atividade foram: coleta $R \$ 295,00$; estria normal $R \$ 330,00$; estria em $V R \$ 380,00$; estria em $V$ especial $R \$ 400,00$; raspa de goma $R \$ 250,00$ e a média salarial dos diaristas foi $R \$ 200,00$.

O salário dos tarefeiros não mostrou qualquer relação com escolaridade, tempo de serviço na atividade, ou número de filhos. Mesmo os trabalhadores contratados como encarregados ou supervisores não tem uma escolaridade maior que o antigo primário em nenhuma das três situações estudadas. Conversando com empresários, verifica-se que a situação se repete na

${ }^{19}$ O salário mínimo na época das entrevistas (fevereiro de 1997) era de $R \$ 112,00$. 
maioria das firmas de resinagem, onde o encarregado e o supervisor, que vão trabalhar com as turmas no campo, têm que ter prática do serviço e capacidade de liderança sabendo ler e escrever o necessário para fazer os apontamentos de cada trabalhador e o controle da produção.

A renda familiar ${ }^{20}$ dos moradores do acampamento estudado teve a seguinte variação: em $20 \%$ dos casos vai de $R \$ 200,00-R \$ 300,00$; em 20\% é de $R \$ 500,00$ - R\$ 600,00, chegando em 14,29\% das famílias à $R \$ 600,00$ - $R \$$ 700,00 . Na colônia, a renda familiar mais comum $(57,14 \%)$ é de $R \$ 112,00-R \$$ 200,00; a seguir em 14,29\% das famílias ela é de $R \$ 500,00$ - $R \$ 600,00$, sendo que apenas em $9,52 \%$ ela atinge o valor de $R \$ 600,00-R \$ 700,00$. No bairro estudado, esta renda se distribui da seguinte maneira: $46,15 \%$ das familias têm rendimentos de $R \$ 200,00$ - $R \$ 300,00 ; 23,08 \%$ obtêm rendimentos de $R \$ 400,00$ - $R \$ 500,00$; sendo que apenas 9,52\% atingem renda de $R \$ 600,00-R \$ 700,00$.

O trabalhador americano, que trabalha na coleta da resina, segundo Lieberman \& Goolrick (1979) recebia U\$ 8.00/tambor ${ }^{21}$ coletado, enquanto na mesma época o coletor brasileiro recebia U\$4.00/tambor. Porém, deve-se levar em conta as condições em que é feita a coleta nas duas situações, pois enquanto o trabalhador americano trabalha em floresta nativa, o que implica em diversidade de idades, produtividade, espécies, etc., no Brasil a atividade é realizada em florestas plantadas, homogêneas em idade, espécie, espaçamento, etc. implicando em percorrer menores distâncias para coletar a mesma quantidade.

Os Autores citam, como exemplo de eficiência na atividade de coleta, um homem que coletou, em quatro dias, 7 tambores. No acampamento estudado, a média é de 3 tambores/homem/dia, segundo o encarregado. Uma mulher contou que, dependendo do talhão, consegue encher até 7 tambores em um dia, sendo este um caso isolado uma vez que segundo os empresários o mínimo de coleta é 2

${ }^{20}$ Considerou-se apenas a renda familiar oriunda da resinagem.

21 Tambor com capacidade de 2001. 
tambores por dia e o máximo que, normalmente, um trabalhador faz é de 4,5 tambores por dia.

Um dos problemas mais freqüentes são as faltas ao trabalho após os fins de semana e feriados, causadas por embriaguez, que são perdoadas em função da produtividade do trabalhador. Não se tolera comportamentos que causem tumultos e transtornos à comunidade. Lieberman \& Goolrick (1979) descrevem situação semelhante entre os trabalhadores da resina nos Estados Unidos. No acampamento estudado procura-se evitar este problema pagando um adicional de $R \$ 6,00$ por fim de semana, ao trabalhador que não falta.

Angeleli et al. (1981) citado por Gnaccarini (1993) comenta os mesmos problemas em relação às faltas e bebidas, comentando ser uma ocorrência normal a ausência de até $50 \%$ ou mais dos indivíduos às segundasfeiras. Outros motivos alegados são doenças e perda da hora, entre os homens, e problemas domésticos, aos sábados, entre as mulheres. Os trabalhadores da resina não trabalham aos sábados, em função da legislação.

Foi observado um grande número de famílias originárias do Paraná, trabalhando na resina, representando $57,14 \%$ dos moradores do acampamento; $19,23 \%$ dos moradores do bairro e 15,38\% dos moradores da colônia. Investigamos os motivos disso, uma vez que o Paraná não possui tradição resineira, tendo porém uma forte tradição madeireira. Contudo apenas 11,71\% desses paranaenses declararam madeireiro como profissão paterna. Consultamos um empresário, e viemos a descobrir que esses trabalhadores do Paraná eram, originalmente bóias frias do café.

Gasques et al., (1977) citado por Gnaccarini, (1993) já afirmava que a renda média anual do bóia-fria e a insegurança do emprego, justificavam a forte atração exercida pelo salário mínimo sobre esses trabalhadores. No caso da resinagem soma-se a possibilidade de ganhos superiores ao salário mínimo, de acordo com a produtividade, como no caso do trabalhador volante, à segurança da carteira assinada e o trabalho estável, enquanto no ambiente urbano a falta de 
qualificação e a atual crise de empregos, tornam a migração para a cidade altamente arriscada.

Também nota-se uma grande quantidade de pessoas originárias da Mesorregião, o que era de se esperar, uma vez que foi aí que a atividade se iniciou no Brasil. Quando começou a resinagem em Pinus tropicais, os mesmos empresários que já trabalhavam na Mesorregião resinando o Pinus elliottii, começaram a ampliar suas atividades para outras regiões do Estado, levando os seus trabalhadores para as novas áreas de exploração.

Atualmente com a expansão das atividades de resinagem para o Triângulo Mineiro, ocorre um novo processo de saída de mão-de-obra da resina, da Mesorregião para lá. Segundo os empresários, apesar de aquela ser uma região rica, com ênfase na pecuária e café, a resina não está perdendo trabalhadores para estas atividades, uma vez que a remuneração é semelhante, porém com as vantagens de serviço permanente e registro em carteira. 


\section{CONCLUSÕES}

A resinagem, no Estado de São Paulo, está ameaçada pelo recuo da área reflorestada com Pinus. O Estado, através do Instituto Florestal, não está ampliando a área reflorestada com a espécie e os reflorestadores preferem plantar - Eucalyptus. Poucos empresários da resina estão dispostos a investir em reflorestamentos próprios, preferindo buscar em outros Estados a floresta em ponto de resinagem. Com isso, está havendo expansão da atividade fora do Estado de São Paulo, em regiões onde os reflorestamentos com Pinus ainda são abundantes. A médio prazo, pode-se prever uma concentração de empresas atuando no Triângulo Mineiro e Nordeste do Paraná.

Nos casos estudados, houve uma atração de trabalhadores volantes da cafeicultura do Paraná. Este trabalhador encontrou na resinagem uma forma de ter uma maior estabilidade de trabalho, com carteira assinada, emprego permanente, salário vinculado ao rendimento e sem exigência de escolaridade.

A legislação e a fiscalização do Ministério do Trabalho fizeram com que os trabalhadores e empresários se adaptassem às novas regras tornando mais difícil a presença de menores de 14 anos $^{22}$ dentro da floresta e obrigando aos empresários o pagamento de vantagens trabalhistas que antes não ocorriam.

${ }^{22}$ Até 1999 esta era a idade mínima para o trabalho do menor e a Legislação que aumentou - limite para 16 anos permite a continuidade dos menores entre 14 e 16 anos que já trabalhavam na época desta mudança. 
Os progressos na atividade da resinagem visam sobretudo minimizar os custos de produção e no momento o maior componente destes é a mão-de-obra. Desta forma, todos os esforços atualmente se concentram na redução da quantidade de mão-de-obra necessária.

As mudanças mais sensíveis na exploração visaram a preservação da árvore: tamanho de estrias, diminuição da concentração da pasta ácida, limitação de largura e altura do painel, estendendo o tempo de resinagem, permitindo-se resinar mais painéis por face e mais faces por árvores, com a intenção de prolongar o tempo da atividade, havendo a cicatrização das partes feridas, em tempo de serem novamente resinadas. 


\section{REFERÊNCIAS BIBLIOGRÁFICAS}

AOKI, H.; CRUZ, S.F. Novas alternativas de resinagem de Pinus. Revista do Instituto Florestal, v.10, n.2, p.123-126, 1998.

AUGUSTO FILHO, ]. Resinas, em busca de alternativas. Silvicultura, n.53, p.16-8, jan./fev. 1994.

BAENA, E.S. Análise da viabilidade econômica da resinagem em Pinus elliottii Engelm. Var. elliottii nas Regiões Sul do Estado do Paraná e Sul e Sudoeste do Estado de São Paulo. Curitiba, 1994. 94p. Tese (Doutorado) - Universidade Federal do Paraná.

BERZAGHI, C. Pinus spp e resinagem. Boletim Técnico do Instituto Florestal, n.2, 1983. 33 p.

BLISS, J.C. \& FLICK, W. A. With a saw and a truck: Alabama pulpwood producers. Forest \& Conservation History, v.38, n.2, p.79-89, April 1994.

BLISS, J.C. Understanding people in the landscape: social research applications for ecological stewardship. In: Toward a scientific and social framework for ecologically-based stewardship of Federal lands and waters. Alabama: s.ed. 1996. (Topic ST-1).

BOLETIM INFORMATIVO MENSAL DA ASSOCIAÇÃO DOS RESINADORES DO BRASIL. Avaré, n.6, ago. 1994. 4p. 
BOLETIM INFORMATIVO MENSAL DA ASSOCIAÇÃO DOS RESINADORES DO ESTADO DE SÃO PAULO. Buri, n. 8, out. 1992. 4p.

BOLETIM TÉCNICO DO INSTITUTO FLORESTAL. São Paulo, v.35, n.1, set. 1981. $48 p$.

BRITO, J.O.; BARRICHELO, L.E.G. Recursos químicos e energéticos florestais. Piracicaba: Escola Superior de Agricultura Luiz de Queiróz, 1978. 46p.

BUCCI, L.A.; RIBAS, C.; ASSINI, J.L. Produção de resina em Pinus elliottii em Campos de Jordão. Boletim Técnico do Instituto Florestal, v.40-A, parte 2, p. 576-583, dez. 1986.

CASER, D.V.; OLIVETTI, M.P.A.; CAMARGO, A.M.M.P. \& ANEFALOS, L.C. Evolução da cobertura florestal no Estado de São Paulo, 1970-95. Informações Econômicas, v. 28, n.5, p. 27-46, maio 1998.

CASTRO, J.L. Potencialidades agronômicas regionais. Capão Bonito, 1997. 3p.

CLEMENTS, R.W. Métodos de moderna resinagem: manual. São Paulo: Instituto Florestal, 1970. $16 \mathrm{p}$.

COUTO, H.T.Z. Disponibilidade de florestas de Pinus para resinagem no Brasil. Silvicultura, n. 33, p. $54-7,1983 . /$ Apresentado ao 2. SEMINÁRIO SOBRE RESINAS DE PINUS IMPLANTADOS NO BRASIL, São Paulo, 1983 - Anais/

DICIONÁRIO Eletrônico Michaelis. Dicionário eletrônico em três línguas: português, espanhol e inglês. (Compact-disc). S.I.: DTS Software Ltda. nov. 1996.

DORMAN, K.W. \& SQUILLACE, A.E. Genetics of slash pine. USDA Forest Service wo Research Paper, Washington, n.20, p.1-20, 1974.

FAGUNDES, E.M. Rotatividade da mão-de-obra na resinagem. Boletim Informativo Mensal da Associação dos Resinadores do Estado de São Paulo (ARESP). Buri, n.2, p.2. abr. 1992. 
FERNANDES, P.S.; OSORIO, R.G.S.; BRITO, J.O.; STAPE, J.L. Efeito exaustivo de estimulantes químicos na resinagem intensiva de Pinus elliottii Eng. var. elliottii. Boletim Técnico do Instituto Florestal, v.42, p.139-148, maio. 1988.

FERNANDES, P.S.; OSÓRIO, R.G.S.; DESTEFANI, J.C.; STAPE, J.L. Estudo do efeito da largura do painel na produção da resina. Boletim Técnico do Instituto Florestal, v. 40-A, parte 2, p.656-665, dez. 1986.

FERRI, M.G.; MENEZES, N.L.; SCANAVACCA, W.R.M. Glossário de termos botânicos. São Paulo: Edgard Blücher. 1969. 199p.

FIGUEIREDO FILHO, A. Influência da resinagem no crescimento de Pinus elliottii Engelm. var. elliottii e sua avaliação econômica. Curitiba, 1991. 138p. Tese (Doutorado) - Universidade Federal do Paraná.

FLORESTAR ESTATISTICO, v.3, n. 9, p.36, 1996.

FONSECA, S.M.; KAGEYAMA, P.Y. Melhoramento genético face à produção de resina. Piracicaba: Instituto de Pesquisas e Estudos Florestais. 1978. 16p (Circular Técnica, 36).

FONSECA, W.S.; BARBOSA; 3.J.; DEWULSKI, N.P.; FIGUEIREDO, M. B. A alimentação do trabalhador florestal: estudo das condições alimentares, nutricionais e econômico-sociais dos Parques Florestais do Instituto Nacional do Pinho. Rio de Janeiro: Biblioteca Brasileira de Nutrição. Serviço de Alimentação da Previdência Social, 1953.125p

FREITAS, A.R. Potencial e limitações das industrias de base florestal no Estado. In: CONGRESSO FLORESTAL BRASILEIRO, 6. Campos do Jordão, 1990. Florestas e meio Ambiente: conservação e proteção, patrimônio social. Anais. Campos do Jordão: SBS/SBEF, 1990. p.129-131.

FUNDAÇÃO FLORESTAL. Plano de desenvolvimento florestal sustentável. São Paulo: A Fundação, 1993. 47p. 
FUNDAÇÃO INSTITUTO BRASILEIRO DE GEOGRAFIA E ESTATISTICA. Censo demográfico. FIBGE, Rio de Janeiro. n.21, 1991.

GARCIA, J.C. Os resineiros do Horto. O Tempo, Assis, 15 jan. 1994.

GARNICA, J.B.; NICOLIELO, N. \& BERTOLANI, F. Melhoramento florestal em Pinus elliottii var. elliottii visando a produção de goma resina. In: CONGRESSO FLORESTAL BRASILEIRO, 4., Belo Horizonte, 1982. Anais. Belo Horizonte: SBS, 1983. p. 291-293.

GARRIDO, M.A.O.; POZ, R.; FREITAS, J.A.; ROCHA, F.T. \& GURGEL GARRIDO, L.M. Resinagem: manual técnico. São Paulo: Páginas \& Letras, 1998. 23p.

GIL, A.C. Métodos e técnicas de pesquisa social. 3 ed. São Paulo: Atlas, 1991. $207 p$.

GNACCARINI, J.C. O trabalho infantil agrícola na era da alta tecnologia. In: MARTINS, J. de S. (Coord.) O massacre dos inocentes: a criança sem infância no Brasil. São Paulo: Hucitec, 1993. cap. 4, p. 81-116.

GOLFARI, L.; CASER, R.L.; MOURA, V.P.G. Zoneamento ecológico esquemático para reflorestamento no Brasil: $2^{\mathrm{a}}$. aproximação. Belo Horizonte: PRODEPEF, 1978. 66p. (PNUD/FAO/IBDF/BRA-45. Série Técnica, n 11)

GRANDE Enciclopédia Larousse Cultural. S.I.: Librairie Larousse. Universo. v. 24. p.4871. s.d.

GURGEL FILHO, O.A. Contribuição à resinagem. São Paulo: Instituto Florestal, 39p. 1972.

GURGEL FILHO, O.A.; SOUZA JUNIOR, H.; VENKOVSKY,R. Resinagem em Pinus elliottii Eng. var. elliottii (Nota prévia). Silvicultura em São Paulo, v.6, p. 15760, 1967. 
GURGEL GARRIDO, L.M. do A.; RIBAS, C.; GARRIDO, M.A. de O. Variabilidade da produção de resina em Pinus elliottii Eng. var. elliottii. Revista do Instituto Florestal, v.6, p.113-128, dez. 1994.

HODGES, A.W. Update on Pine oleoresin tapping by the borehole method. Forest Chemicals Review. p.5-12, May/June 1998.

HODGES, A.W.; WILLIANS, G. Pine gum in a bottle? A sealed collection system for production of high purity oleoresin. Naval Stores Review, p.2-8, May/June, 1993.

HOMA, M. Considerações técnicas e potencialidade da produção de derivados de resinas de Pinus. Silvicultura, n.33, p.61-67. São Paulo, 1983./ Apresentado ao 2. Seminário sobre resinas de Pinus implantados no Brasil, São Paulo. 1983. - Anais/.

IF SÉRIE REGISTROS. Instituto Florestal. São Paulo, n. 12, set. 1994. 31p.

INSTITUTO BRASILEIRO DE GEOGRAFIA E ESTATISTICA Censos econômicos de 1985 - Municípios: industria, comércio e serviços. Rio de Janeiro: IBGE, 1985. v.3 - Região Sudeste.

INSTITUTO BRASILEIRO DE GEOGRAFIA E ESTATISTICA. Anuário estatístico do Brasil, Rio de Janeiro: IBGE, 1996. v.56, 1996.

INSTITUTO FLORESTAL. Instituto Florestal de São Paulo. São Paulo, 1980. 32p.

KERLINGER, F.N. Metodologia da pesquisa em ciências sociais: um tratamento conceitual. São Paulo: EPU/EDUSP, 1979.

KRONKA, F.J.N.; MATSUKUMA, C.K.; NALON, M.A. et al. Inventário florestal do Estado de São Paulo. São Paulo: Instituto Florestal, 1993. 199p.

LIBERMAN, P.; GOOLRICK, C. Naval stores ages-old, but few like living in past. The Atlanta journal and Constitution, 02 dec. 1979. 
LIEBERMAN, P. \& GOOLRICK, C. Endless debt haunts turpentiners: The underpaid and under-protected. The Atlanta Journal and Constitution, Atlanta, 02 dez. 1979.

LIMA, W.P. Impacto ambiental do eucalipto. 2.ed. São Paulo: Universidade de São Paulo, 1996. 302p.

MARTINS, Z. Agricultura paulista: uma história maior que 100 anos. 1. ed. São Paulo: Secretaria de Agricultura e Abastecimento, 1991. 582p.

MARTINS, Z.; LAPOLLA, P. O Instituto Florestal e sua trajetória. São Paulo. Secretaria de Agricultura e Abastecimento/Instituto Florestal. 1987.

NICOLIELO, N. Obtenção de resina em regiões tropicais Silvicultura, n.33. p.2732, 1983./ Apresentado ao 2. Seminário sobre resinas de Pinus implantados no Brasil, São Paulo. 1983 - Anais/.

NOGUEIRA, O. Família e comunidade: um estudo sociológico de Itapetininga/SP. Rio de Janeiro: MEC,1962. 541p.

NORONHA, J.F.; FONSECA FILHO, H. \& MELGAÇO, S.B. Características socioeconômicas dos membros das associações de seringueiros beneficiadores de látex através de miniusinas no Estado do Acre. O Solo, n.79, p.78-82, dez., 1987.

NOVO Dicionário Aurélio. Dicionário Aurélio Eletrônico. (Compact-disc). 2 ed. s.I.: Nova Fronteira. Ago. 1995.

OSÓRIO, R.G.S. Aspectos operacionais da resinagem. Silvicultura, n.33. p.11-13, 1983./Apresentado ao 2. Seminário sobre resinas de Pinus implantados no Brasil, São Paulo. 1983 - Anais/.

PINO, F.A. (Org.) et al. Levantamento censitário de unidades de produção agrícola do Estado de São Paulo - LUPA. São Paulo: IEA/CATI/SAA, 1997. 4 v. 
PIZA, M. Os municípios do Estado de São Paulo: informações interessantes. São Paulo: Secretaria da Agricultura, Commercio e Obras Públicas do Estado de São Paulo. Depto. Estadual do Trabalho. Serviço de Publicações, 1924. 303p.

POLESI, A. Resinagem é hoje um bom negócio. Silvicultura, n. 20, p.32-37, set./out. 1981.

QUEDA, O. A extensão rural no Brasil: da anunciação ao milagre da modernização agrícola. Piracicaba, 1987. 201p. Tese (Livre-Docência) - Escola Superior de Agricultura "Luiz de Queiroz", Universidade de São Paulo.

RIBAS, C.; GURGEL GARRIDO, L.M.A.; GARRIDO, M.A.O.; ASSINI, J.L.; BOAS, O.V. Produção de resina e influência no crescimento dendrométrico em árvores de Pinus elliottii Eng. var. elliottii, de diferentes diâmetros. Boletim Técnico do Instituto Florestal, v.38, n.2, p. 155-163, ago. 1984.

ROMANELLI, R.C. Variabilidade genética para produção de resina associada às características de crescimento em uma população de Pinus elliottii var. elliottii Engelm. na Região de Itapetininga - SP. Piracicaba, 1988. 101p. Dissertação (M.S.) - Escola Superior de Agricultura "Luiz de Queiróz", Universidade de São Paulo.

ROSTELATO, C. Pinus dá resina e serve para múltiplos usos. Estado de São Paulo. Suplemento agrícola, São Paulo, 22 maio 1996. p. 12-3.

SAINT-HILAIRE, A. DE. Viagem à Província de São Paulo e resumo das viagens ao Brasil, Província Cisplatina e Missões do Paraguai. 2. ed. São Paulo: Livraria Martins, 1940. p. 266.

SANTOS, A.S. dos. Guia prático de tradução inglesa. São Paulo: Cultrix/EDUSP. 1981. $305 p$.

SÃO PAULO. Secretaria da Agricultura. Zoneamento agrícola do Estado de São Paulo. São Paulo: CATI, dez. 1974. 165p. v.1. 
SECRETARIA DE ECONOMIA E PLANEJAMENTO. Diagnóstico regional da Região de Governo de Itapetininga. Itapetininga: Coordenadoria de Ação Regional. ERP de Itapetininga. 1991. 43p.

SERVIÇO NACIONAL DE FORMAÇÃO PROFISSIONAL RURAL. Silvicultor, V.13, 1979. 524p. (Coleção Básica Rural).

SOCIEDADE BRASILEIRA DE SILVICULTURA. Legislação Florestal Brasileira. Programa Legiflor 1.1 (software). São Paulo, 1996. 3 disquetes.

TREE-CD. catálogo coletivo de livros e teses (compact disc), 1997.

TRIVIÑOS, A.N.S. Introdução à pesquisa em ciências sociais: a pesquisa qualitativa em educação. 1 ed. São Paulo: Atlas, 1987. 175 p.

VICTOR, M.A.M. O reflorestamento incentivado, 10 anos depois. Silvicultura, n. 6, p. 18-46, maio-jun. 1977. 


\section{SUPLEMENTOS}

\section{Questionários}

1. Profissão:

2. Sexo: () masculino () feminino

3. Idade: () menos de 14 anos () $14-18$ anos

() $18-25$ anos () $25-35$ anos () $>35$ anos

4. Estado civil: () casado ( ) solteiro ( ) viuvo ( ) amasiado

5. Escolaridade: () analfabeto ( ) $4^{\mathrm{a}}$. série do $1^{\circ} \cdot \operatorname{grau}() 1^{\circ} \cdot$ grau incompleto

() $1^{\circ}$. grau completo () $2^{\circ}$.grau incompleto ( ) $2^{\circ}$. grau completo $\quad$ ( ) superior

6. Quantas crianças até 14 anos moram aqui? Quantas estão na escola?

7. Número de filhos: $\begin{array}{llllllllll}0 & 1 & 2 & 3 & 4 & 5 & 6 & 7 & 8 & >8\end{array}$

8. Possui alguma propriedade: () casa () terreno () sitio ()chácara

9. Número de pessoas que residem na casa:

10. Número de pessoas, da casa, que trabalham na resina: c/carteira ; s/carteira. 
11. Quanto, o chefe da família ganha por mês: () até $R \$ 112,00$ 200,00

() $R \$ 200,00-R \$ 300,00$

() $R \$ 300,00-R \$ 400,00$

() $R \$ 400,00-R \$ 500,00$

() $R \$ 500,00-R \$ 600,00$

() $R \$ 600,00-R \$ 700,00$

() mais de $R \$ 700,00$

12. Quanto a família recebe por mês: ( ) até $R \$ 112,00$

$\begin{array}{ll}\text { () } R \$ 112,00-R \$ 200,00 & \text { () } R \$ 200,00-R \$ 300,00\end{array}$

$\begin{array}{ll}\text { () } R \$ 300,00-R \$ 400,00 & \text { () } R \$ 400,00-R \$ 500,00\end{array}$

$\begin{array}{ll}\text { () } R \$ 500,00-R \$ 600,00 & \text { () } R \$ 600,00-R \$ 700,00\end{array}$

() mais de $R \$ 700,00$

13. Qual o salário registrado em carteira: ( ) não tem registro

() até $R \$ 112,00$

( ) $R \$ 112,00-R \$ 200,00$

() $R \$ 200,00-R \$ 300,00$

() $R \$ 300,00-R \$ 400,00$

() $R \$ 400,00-R \$ 500,00$

() $R \$ 500,00-R \$ 600,00$

() $R \$ 600,00-R \$ 700,00$

() mais de $\mathrm{R} \$ 700,00$

() tarefeiro rural

14. Tem conta em banco: () sim () não

15.Tem caderneta de poupança: ( ) sim () não

16. Qual o horário de trabalho:

17. Forma de contrato: () salário fixo () produtividade 
() salário fixo e produtividade

18.Como fica sabendo onde precisa de empregados para resina:

19.Com quem aprendeu a resinar?

20.Há quanto tempo trabalha na resinagem?

21. Há quanto tempo mora neste acampamento?

22. Onde nasceu: Cidade

Estado

23. O que o pai era: () aforante () pequeno proprietário

() posseiro () arrendatário () parceiro (meeiro) (terça)

() empregado da resinagem () trabalhador braçal() madereiro

24. Local de residência: ( ) acampamento( ) casa de alvenaria

25. Se mora em casa de alvenaria: ( ) própria ( ) alugada ( "da firma"

26. Local da casa: ( ) zona rural () na cidade () colônia da firma

27. Tem esgoto: () sim () não

28. Tem água encanada: ( ) sim ( ) nāo

29. Tem luz elétrica: ( ) sim () não

30. Se tem luz elétrica, quais eletrodomésticos possui: () geladeira

() televisāo () aparelho de som () videocassete

( ) ferro elétrico ( ) liqüidificador 


\section{Trabalhos sobre Resinagem}

1967

1967

1970

1970

1971

1972

1972

1972

1974

1976

Pinus spp e resinagem

BERZAGHI, C. (IF)

Resinagem em Pinus elliottii var. elliottii

GURGEL FILHO, O.A. ET AL. (IF)

Métodos da moderna resinagem

CLEMENTS, R.W. (IF)

Definição da freqüência de aplicação de estimulante químico na resinagem de Pinus elliottii

KRONKA, F.J. ET AL. (IF)

Melhoramento de pinus elliottii com vistas à produção de resina

GURGEL FILHO, O.A. (IBDF)

Contribuição à resinagem

GURGEL FILHO, O.A. (IBDF)

Melhoramento de Pinus elliottii var. elliottii

GURGEL FILHO, O.A. (Congresso Anual da SBPC - 23)

Novos subsídios à resinagem de Pinus elliottii

GURGEL FILHO, O.A. \& VENCOVSKY, R. (Congresso Florestal

Brasileiro 2)

Sobre as possibilidades de um aproveitamento econômico da resina no Brasil

SANDERMAN, W. (ibdf)

Resinagem de Pinus elliottii densa e Pinus oocarpa

SILVA, H.M. ET AL. (IF) 
1977

1978

1978

1978

1978

1978

1980

1980

1982

1982
Influencia do diâmetro e da copa na produção de resina

GURGEL FILHO, O.A. \& GURGEL GARRIDO, L.M.A.

Fatores que influem na resinagem de Pinus

GURGEL FILHO, O.A. \& FARIA, A.J. (IPEF)

Melhoramento genético face à produção de resina

FONSECA S.M. \& KAGEYAMA, P.Y. (IPEF)

Resinagem em escala comercial na Cia. Agro Flor. Monte Alegre, Agudos/SP

NICOLIELO, N. \& BERTOLANI, F. (CBF,3)

Condições climáticas e suas influencias sobre a produção de resina de pinheiros tropicais

BRITO, J.O. et al. (IPEF)

Crescimento juvenil de Pinus elliottii de alto e baixo rendimento de resina no sul de São Paulo

SHIMIZU, J.Y. (Brasil Florestal)

A potencialidade de resinagem de 4 espécies de Pinus tropicais na região de Sacramento/MG

CAPITANI, L.R. et al. (IPEF)

Qualidade do breu e terebintina de pinheiros tropicais

BRITO, J.O. (ipef)

Método rápido para estimar produção de resina em árvores de Pinus BRITO, J.O. et al. (IF)

Seleção massal de fenótipos visando alta produção de resina em

Pinus elliottii Eng. var. elliottii

RIBAS, C. et al. (IF) 
Eleição de árvores superiores para produção de resina GURGEL GARRIDO, L.M.A. (CFB,4)

Produção de resina de 3 espécies/variedades de Pinus tropicais GARRIDO, M.A.O. et al. (IF) Melhoramento florestal em Pinus elliottii var. elliottii, visando a produção de goma-resina GARNICA, J.B. et al. (cbf, 4)

1982 Programa de melhoramento do IF em Pinus elliottii var. elliottii para produção de goma-resina

ROMANELLI, R.C. et al. (CFB,4)

1983 Aspectos operacionais da resinagem

OSORIO, R.G.S. (Silvicultura)

1983 Resinagem de Pinus caribaea bahamensis

RIBAS, C. et al. (CFB,4)

Obtenção de resina de Pinus de regiões temperadas

SCHREINER, C.A. (Silvicultura,33:33-38)

1983 Pesquisas em resinagem

GARRIDO, M.A.O. et al. (Silvicultura, 33:48-53)

1984 Estudo matemático de alguns componentes da produção diária de resina

GURGEL GARRIDO, L.M. do A. et al. (IF)

1984 Resinagem de Pinus elliottii var. elliottii densa e Pinus oocarpa SILVA, H.M. et al. (IF) 
1984 Produção de resina e influência no crescimento dendrométrico em árvores de Pinus elliottii var. elliottii de diferentes diâmetros RIBAS, C. et al. (IF) Resinagem de Pinus: técnicas operacionais e estimulantes químicos RIBAS, C. et al. (IF)

1985 Resultados experimentais em resinagem de Pinus na Eucatex Florestal

FERNANDES, P.S. et al.

1986 Resinagem de Pinus elliottii: efeito da quantidade de ácido sulfúrico na produção de resina e na altura da face de resinagem

RIBAS, C. et al. (IF)

1986

Seleção de Pinus tropicais para produção de resina GURGEL GARRIDO, L.M. do A. \& GARRIDO, M.A. de O. (IF)

1986 Produção de resina de Pinus elliottii em Campos do Jordão

BUCCI, L.A. et al. (IF)

1986 Efeito da concentração da pasta na produção de resina FERNANDES, P.S. et al. (IF)

1986 Efeito da largura do painel na produção de resina FERNANDES, P.S. et al. (IF)

Comparação entre técnicas de micro-resinagem GURGEL GARRIDO, L.M. do A. et al. (IF)

Variabilidade genética para produção de resina associada às características de crescimento em uma população de Pinus elliottii var. elliottii na região de Itapetininga/SP

ROMANELLI, R. (Mestrado) 
1988

1989

1989

1990

1993

1993

1994

1995

1996

Teste de progênie precoce de meio irmãos de Pinus elliottii var.

elliottii de árvores superiores para produção de resina.

GURGEL. GARRIDO, L.M. do A. (IF)

Efeito de estimulantes químicos na resinagem intensiva do Pinus

elliottii var. elliottii

FERNANDES, P.S. et al. (IF)

Avaliação da produção de resina em progênies de Pinus elliottii var.

elliottii em idade juvenil

OLIVEIRA, J.G. (Dissertação de mestrado)

Seleção individual em Pinus elliottii var. elliottii para produção de

resina no IF

GURGEL GARRIDO, L.M.A. et al. (IF)

Alterações nas estimativas dos parâmetros genéticos de produção de resina de Pinus elliottii var. elliottii, em conseqüência de desbastes.

GURGEL GARRIDO, L.M.A. \& KAGEYAMA, P.Y. (IF)

Evolução com a idade de parâmetros genéticos de Pinus elliottii var.

elliottii, selecionado para produção de resina

GURGEL GARRIDO, L.M.A. \& KAGEYAMA, P.Y. (IF)

Seleção precoce em progênies de Pinus elliottii var. elliottii

ROMANELLI, R.C. (IF)

Variabilidade genética da produção de resina, DAP e altura em Pinus caribaea var. bahamensis

GURGEL GARRIDO, L.M.A. et al (IF)

Novas alternativas de resinagem de Pinus

AOKI, H. \& CRUZ, S.F. ( $3^{\circ}$. Encontro sobre goma resina) 
Sistema fechado de resinagem

FERNANDES, P.S. et al. ( $3^{\circ}$. Encontro sobre Goma Resina) 